\title{
Depth-to-basement study for the western Polish Outer Carpathians from three-dimensional joint inversion of gravity and magnetic data
}

\author{
Mateusz MIKOŁAJCZAK ${ }^{1, *}$, Jan BARMUTA², Małgorzata PONIKOWSKA ${ }^{1}$, Stanisław MAZUR ${ }^{1}$, \\ Krzysztof STARZEC ${ }^{2}$ \\ ${ }^{1}$ Institute of Geological Sciences, Polish Academy of Sciences, Senacka str. 1, 31-002 Kraków, Poland; m.mikolajczak@ingpan. \\ krakow.pl \\ ${ }^{2}$ AGH - University of Science and Technology, Faculty of Geology, Geophysics and Environmental Protection, Adama Mickiewicza \\ ave. 30, 30-059 Kraków, Poland \\ * Corresponding author
}

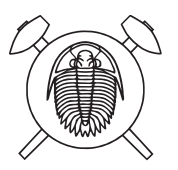

\begin{abstract}
Results of a depth-to-basement study are presented for the westernmost Polish Outer Carpathians. The gravity data are inverted for the top of the Precambrian basement using horizons from 2-D gravity and magnetic forward models and well tops as input depth measurements. 2-D models, used in the study, are built upon depth converted seismic profiles. The results are visualized as an isobath map for the top of the Precambrian basement, complemented with the qualitative structural interpretation of gravity and magnetic anomaly maps. The outcome of 3-D joint inversion of the gravity data and depth measurements shows the Precambrian crystalline basement deepening southward from c. 1 to almost $7 \mathrm{~km}$ b. s. l. Consequently, an approximately $2 \mathrm{~km}$ thick wedge of autochthonous sediments, thickening southward, is embraced between the crystalline basement and a sole detachment of the Carpathian fold-and-thrust belt, imaged by seismic data. Since the modelled top of the crystalline basement is roughly parallel to the Moho, suggesting no extension-related thinning in Mesozoic, the autochthonous sediments are likely of pre-Permian age. A positive magnetic anomaly in the south of the study area is presumably associated with the presence of an elongated body of intermediate to mafic rocks in the basement of the Brunovistulian Terrane. These rocks may represent a relic of a Cadomian magmatic arc comparable to that existing in the Brno Massif of southern Moravia.
\end{abstract}

Keywords: Joint inversion, gravity and magnetic data, Outer Western Carpathians, Precambrian basement, Brunovistulian terrane Received: 23 September 2020; accepted: 24 February 2021; handling editor: A. Guy

\section{Introduction and motivation}

The Precambrian crystalline basement is one of the leastrecognized structural aspects of the Polish Outer Carpathians, where a thick pile of nappes rests upon the slope of the North European Platform (Fig. 1). This is related to poor seismic imaging of structure beneath the Carpathian nappes and scarcity of boreholes penetrating crystalline basement. The depth-to-basement maps of this region (Paul et al. 1996; Grabowska et al. 1998; Buła and Habryn 2008) are low resolution due to an insufficient number of boreholes that have reached the top of the crystalline basement and mostly rely on interpolation between them. Besides, basement grids derived from seismic refraction data (Majdański 2012; Grad and Polkowski 2016) or passive seismic experiments (Alasonati Tašárová et al. 2016) suffer from coarse coverage, especially in the Carpathians region. Therefore, this study's main goal is to use good quality gravity data for a three-dimensional joint inversion of gravity and depth measurements according to the method by Barnes and Barraund (2012). Basement depth estimates used in the inversion exercise are derived from two-dimensional (2-D) forward gravity models that were built upon seismic reflection lines. The results are additionally constrained by qualitative structural interpretation of gravity and magnetic anomaly maps. The results reveal basement control on a structural style and wedge geometry of the Carpathian thin-skinned fold-and-thrust belt.

\section{Geological settings and previous geophysical investigations}

The Outer Carpathians (OC) are a thin-skinned fold-andthrust belt that was emplaced on the southern margin of the North European Platform (NEP) during the Alpine collision (e.g., Golonka et al. 2006, Fig. 1). This fold-andthrust belt consists of several nappes detached from their basement and thrust north and east. Based on the facies distribution, it is assumed that each nappe corresponds to a separate basin or its discrete part (e.g., Książkiewicz 1960; Golonka et al. 2000; Oszczypko et al. 2004). Within the research area, the following units are distinguished from the south to north and from the top to base of structural profile: the Magura, Dukla, the Silesian and the Sub-Silesian Units (e.g., Oszczypko 2006; Ślączka et 


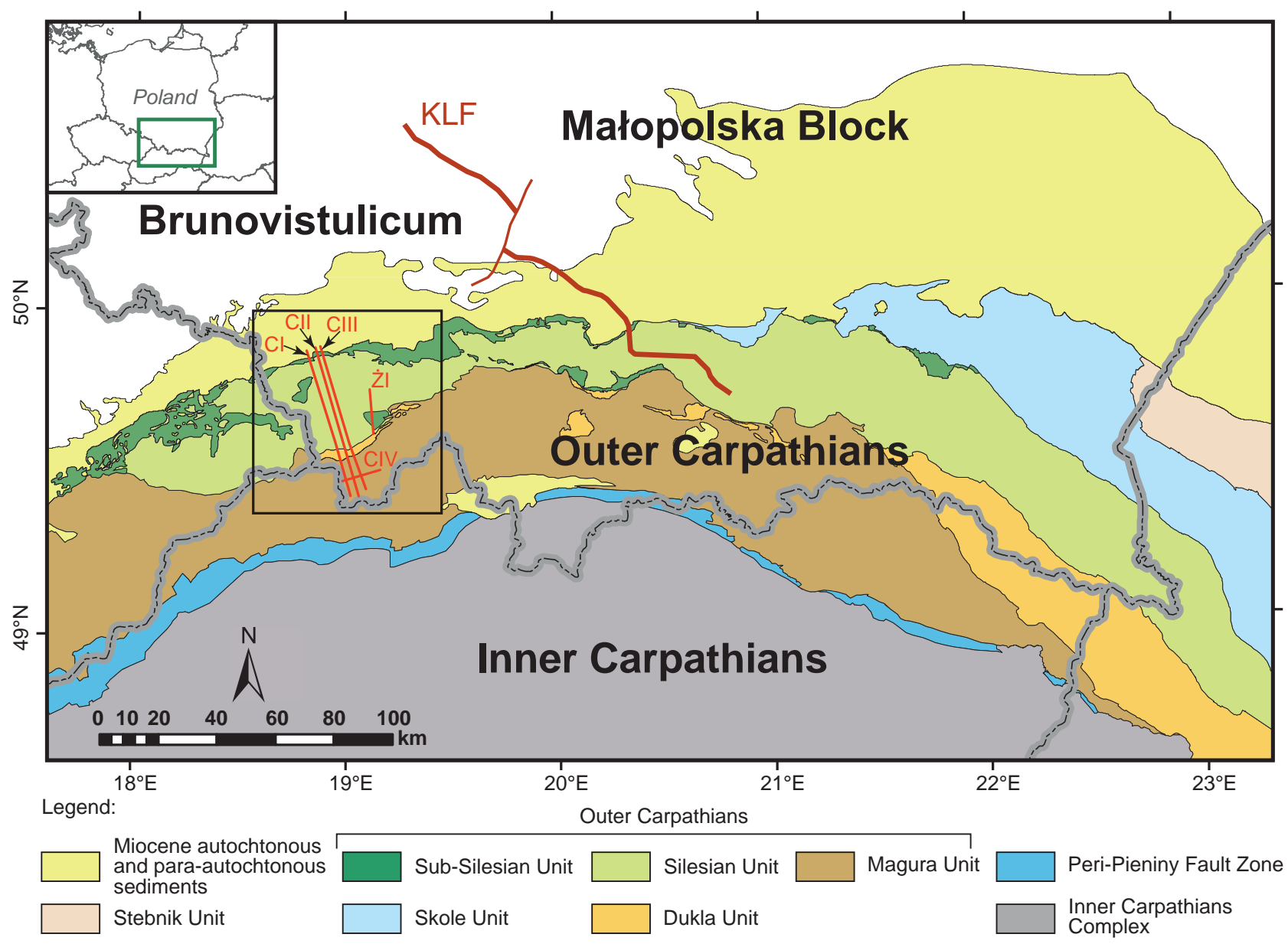

Fig. 1 Location of the study area overlaid on the simplified geological map of the Polish Outer Carpathians. CI, CII, CIII, CIV and ŻI stands for Carpathica I, II, III, IV and Żywiec I 2-D models, respectively. KLF - Kraków-Lubliniec Fault. Green box in the inset shows the map location. Black rectangle indicates the study area.

al. 2006; Gągała et al. 2012; Barmuta et al. 2019). These units represent thrusts over autochthonous Miocene fore- land strata that are partly imbricated, forming the youngest and most external part of the Outer Carpathians (e.g.,

Tab. 1 Depth to the crystalline basement in selected wells in Poland and Czech Republic (depth in meters below ground level)

\begin{tabular}{|c|c|c|}
\hline Well name & Depth to the top of the crystalline basement [m] & Lithology of the crystalline rocks \\
\hline Jablunkov-1 & $3200 \mathrm{MD}$ & diorites (Picha et al., 2006) \\
\hline Dolní Lomná-3 & $1962 \mathrm{MD}$ & metamorphic rocks (Picha et al. 2006) \\
\hline Ustroń C-1 & $1700 \mathrm{MD}$ & Central Geological Database 2020 \\
\hline Ustroń IG-3 & $1728 \mathrm{MD}$ & $\begin{array}{l}\text { gneisses and mica schists (Linnemann et al. 2008; Central } \\
\text { Geological Database 2020) }\end{array}$ \\
\hline Kęty 7 & $1673 \mathrm{MD}$ & granites (Linnemann et al., 2008 Central Geological Database 2020) \\
\hline Roczyny 3 & $1790 \mathrm{MD}$ & granites (Linnemann et al., 2008 Central Geological Database 2020) \\
\hline Andrychów 3 & $2387 \mathrm{MD}$ & $\begin{array}{l}\text { gabbros and gabbronorites (Buła and Żaba 2008; Linnemann et al. } \\
\text { 2008; Central Geological Database 2020) }\end{array}$ \\
\hline Andrychów 4 & $2377 \mathrm{MD}$ & schists (Linnemann et al. 2008; Central Geological Database 2020) \\
\hline Andrychów 6 & $2538 \mathrm{MD}$ & $\begin{array}{l}\text { anchimetamorphic siltstones, mudstones and sandstones (Linnemann } \\
\text { et al. 2008; Central Geological Database 2020) }\end{array}$ \\
\hline Ślemień 1 & $3188 \mathrm{MD}$ & $\begin{array}{l}\text { anchimetamorphic siltstones, mudstones and sandstones (Linnemann } \\
\text { et al. 2008; Central Geological Database 2020) }\end{array}$ \\
\hline Łodygowice IG-1 & $1732 \mathrm{MD}$ & $\begin{array}{l}\text { gneisses, granitogneisses and mica schists (Central Geological } \\
\text { Database 2020) }\end{array}$ \\
\hline Bystra IG-1 & $3561 \mathrm{MD}$ & $\begin{array}{l}\text { gneisses, mica schists (Linnemann et al. 2008; Central Geological } \\
\text { Database 2020) }\end{array}$ \\
\hline
\end{tabular}

MD - (measured depth) is the length of the borehole 
Moryc 2005; Oszczypko 2006). The Magura Unit consists of several thrust sheets that are jointly thrust over the Dukla Unit. The latter comprises a system of imbricated thrust sheets, forming a duplex structure. At their northern termination, these thrust sheets outline a wedge-shaped geometry of the Silesian Unit's southern termination (Starzec et al. 2017). The Silesian Unit consists of c. $5500 \mathrm{~m}$ thick continuous sequence of Upper Jurassic to Oligocene sediments and forms a structure uniformly dipping to the south at an angle of $20^{\circ}$.

In the western part of the Polish OC, the crystalline basement of the NEP is composed of rocks of the Brunovistulian Terrane (BT). The BT represents a periGondwana terrane that was accreted to Baltica in the late Ediacaran-early Cambrian (Żelaźniewicz et al. 2020 and references therein). The BT is composed of crystalline rocks mainly of Neoproterozoic age with some Paleoproterozoic-Neoarchean elements (Żelaźniewicz et al. 2009, 2020; Hanžl et al. 2019) that are partly covered by the upper Ediacaran anchimetamorphic flysch-like sediments and by the Cambrian and Ordovician sedimentary rocks (Buła and Habryn 2011). The top of the lower Palaeozoic sequence is marked by a regional erosional unconformity above which Devonian and Carboniferous terrigenous clastic rocks and carbonates are observed (e.g., Buła and Żaba 2008; Buła and Habryn 2011).

The crystalline rocks of the BT are mostly represented by gneisses and granitoids as proved by boreholes drilled within the study area in Poland and the Czech Republic (Tab. 1). Gneissic boulders reported from the southern part of the Silesian Unit (Starzec et al. 2017) also belong to the Precambrian basement of the BT (Gawęda et al. 2019). The existence of isolated bodies of intermediate and mafic rocks, as diorites, gabbros or gabbronorites, e.g., the Jablunkov Massif, was also proved (e.g., Gnojek and Hubatka 2001; Picha et al. 2006). The direct link between positive magnetic anomalies and basement hosted bodies of mafic rocks was demonstrated by Gnojek and Hubatka (2001), Grabowska et al. (2007) and Barmuta et al. (2019).

\section{Dataset}

\subsection{Gravity data}

The gravimetric initial data set was created by merging grids from two different sources. The base gravity grid covers the Żywiec area within Poland and was provided by the National Geological Archive (Central Geological Database 2020) operated by the Polish Geological Institute (http://baza.pgi.gov.pl/). The gravity database contained measurements derived from 11000 ground stations and gridded using a minimum curvature algorithm with a resolution of $500 \mathrm{~m}$ (Fig. 2a). The gravity data included a complete Bouguer correction based on a digital terrain model and a slab density of $2.67 \mathrm{~g} \cdot \mathrm{cm}^{-3}$.

To include the entire study area, the gravity data covering the Czech Republic and Slovakia were extracted from the open-source global gravity grid (Sandwell et al. 2014) version 27.1 that was downloaded from the Scripps Institution of Oceanography, USA. The data were regrided with a $500 \mathrm{~m}$ interval. A complete Bouguer correction has been applied to the gravity data. Both grids were merged using the Grid Knit tool (suture method) from the Oasis montaj $^{\mathrm{TM}}$ geophysical package. The gravity ellipsoid used was GRS 1980 (Geodetic Reference System 1980; Moritz 1980), and theoretical gravity was based on the WGS84 gravity formula.

\subsection{Magnetic data}

The magnetic data set includes a combination of two grids covering the study area (Fig. 2b). Data within the Polish territory were acquired from the Central Geological Database (2020) and comprised almost 19000 measurement points of total magnetic intensity (TMI) that was upward continued to $500 \mathrm{~m}$ mean terrain clearance. The reduction-to-pole (RTP) transformation was primarily calculated for the magnetic data to remove the effect of the skewness of the induced magnetization that deforms and shifts the anomalies with respect to magnetic sources. The magnetic data were gridded at a $250 \mathrm{~m}$ interval using a minimum curvature algorithm.

The remaining area has been supplemented with the open-source magnetic data, which were extracted from the version 3 of the EMAG-2 (Earth Magnetic Anomaly Grid) data set. The grid was provided by National Centres for Environmental Information, National Oceanic, and Atmospheric Administration (Meyer et al. 2016). EMAG-2v3 is a global Earth Magnetic Anomaly Grid compiled from satellite, ship, and airborne magnetic measurements. The RTP (Reduction-to-the Pole) transformation has been applied to the data.

\subsection{Seismic data}

Seismic data used for this study were acquired in 2014 (lines: $8-2-14 \mathrm{~K}, 12-2-14 \mathrm{~K}, 14-2-14 \mathrm{~K}$ and $16-21-4 \mathrm{~K}$ ) and in 1979 (line 4-8-79K) (Figs 3, 4 and 5), using a dynamite source. For lines 8-2-14K, 12-2-14K, 14-2-14K and $16-21-4 \mathrm{~K}$ planned shot point and receiver point spacing was $40 \mathrm{~m}$ and $20 \mathrm{~m}$, respectively. The maximal offset was 6000 meters, and the fold number reached 170. The acquisition scheme for line 4-8-79K anticipated 50 meters spacing for both shot points and receivers. The resulting fold number was 12 with a maximum offset of 2000 meters. Especially, for lines 8-2-14K, 12-2-14K, $14-2-14 \mathrm{~K}$ and $16-21-4 \mathrm{~K}$ located to the south, where the 

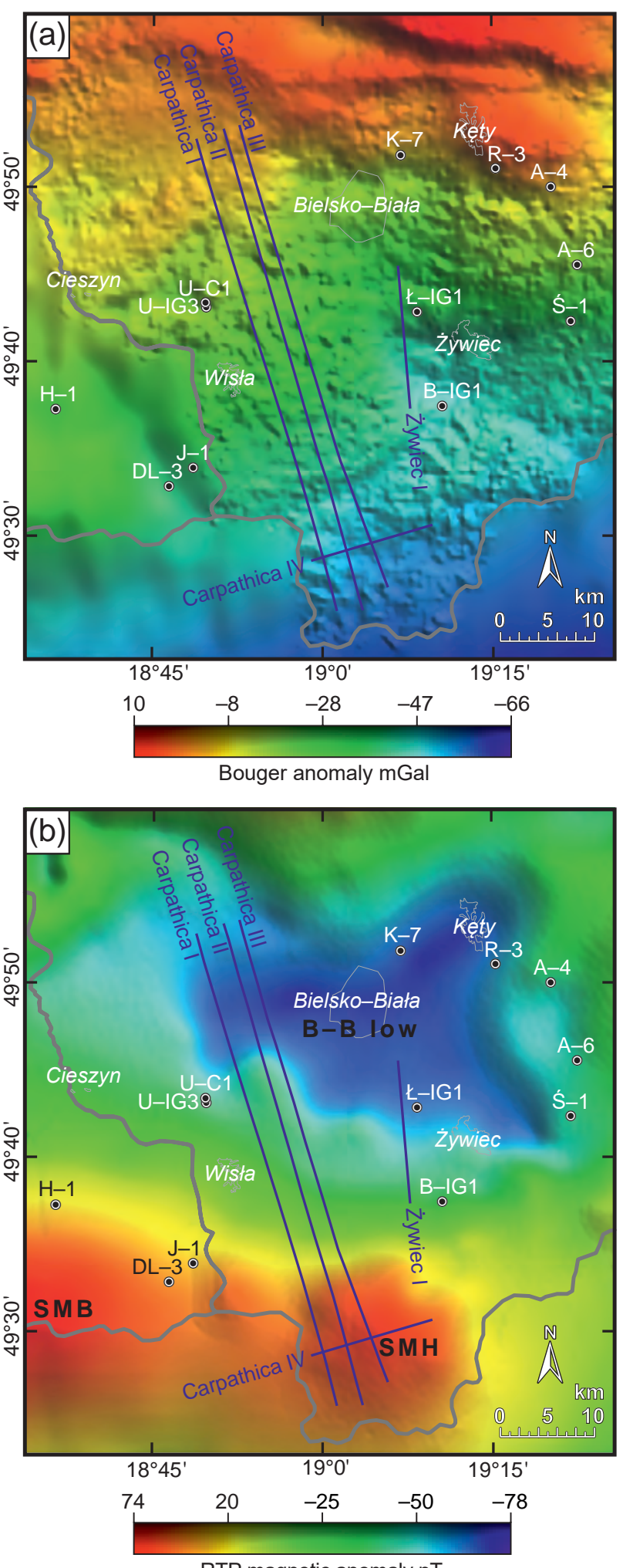

Legend:

Wells reaching crystalline

- basement

_ 2D models localization terrain conditions were difficult, numerous shot points were omitted, which had an impact on final data quality.

The seismic data were initially processed in the time domain. Based on the interpretation and velocity field used for pre-stack time migration, an initial velocity field for pre-stack depth migration (PreSDM) was created and manually updated during subsequent iterations. Because of the lack of deep boreholes with adequate measurements (e.g., check shots, DT and RHOB curves) in the vicinity of the seismic profiles, it was impossible to calibrate the results of the PreSDM precisely, and thus the depth of horizons may be reproduced with some uncertainty.

The final PreSDM versions of all lines were used during the interpretation. Due to the unavailability of synthetic seismograms, the lithostratigraphic horizons were tied to the seismic events based on the geological maps. The quality of seismic data did not allow for detailed interpretation. However, the main structural features within the Carpathian nappes were distinguished. Significantly, on the seismic lines lying to the south, a distinctive seismic horizon interpreted as a top of the pre-Miocene sedimentary cover of the BT occurs. On seismic line 4-8-79K located to the NE, discontinuous and shredded seismic horizons are present within the Carpathian units, making the interpretation difficult and highly ambiguous. Below the Carpathian units, two almost parallel seismic horizons are visible. The stratigraphic position of these horizons is uncertain. Based on the results of deep boreholes within the study area and its vicinity, as well as the velocity properties derived from the PreSDM velocity model, the lower horizon likely represents the top of the crystalline basement. The upper one may represent the erosional top of the anchimetamorphic Ediacaran, Palaeozoic sedimentary cover of the BT, or post-Variscan Mesozoic sediments.

\subsection{Well data}

Information from numerous boreholes was used to constrain a depth to the crystalline basement and densities and lithology for each rock complex. Data were derived from the Polish Central Geological Database or compiled from the literature (Picha et al. 2006; Grabowska et al. 2007; Buła and Żaba 2008; Bojdys et al. 2008). A dozen of public domain wells from Poland (Ustroń C-1, Ustroń

Fig. 2 Potential field data used in modelling: (a) Bouguer gravity anomaly map, (b) Reduced-to-Pole magnetic anomaly map. B-B low - Bielsko Biała magnetic low; SMB - South Moravian-Beskydy magnetic high; SMH - Sól magnetic high. Boreholes abbreviations: A-4 - Andrychów 4; A-6 - Andrychów 6; B-IG1 - Bystra IG-1; DL-3 - Dolní Lomná 3; H-1 - Hnojník 1; J-1 - Jablunkov 1; K-7 Kęty 7; Ł-IG1 - Łodygowice IG-1; R-3 - Roczyny 3; Ś-1 - Ślemień 1; U-C1 - Ustroń C-1; U-IG3 - Ustroń IG-3. 


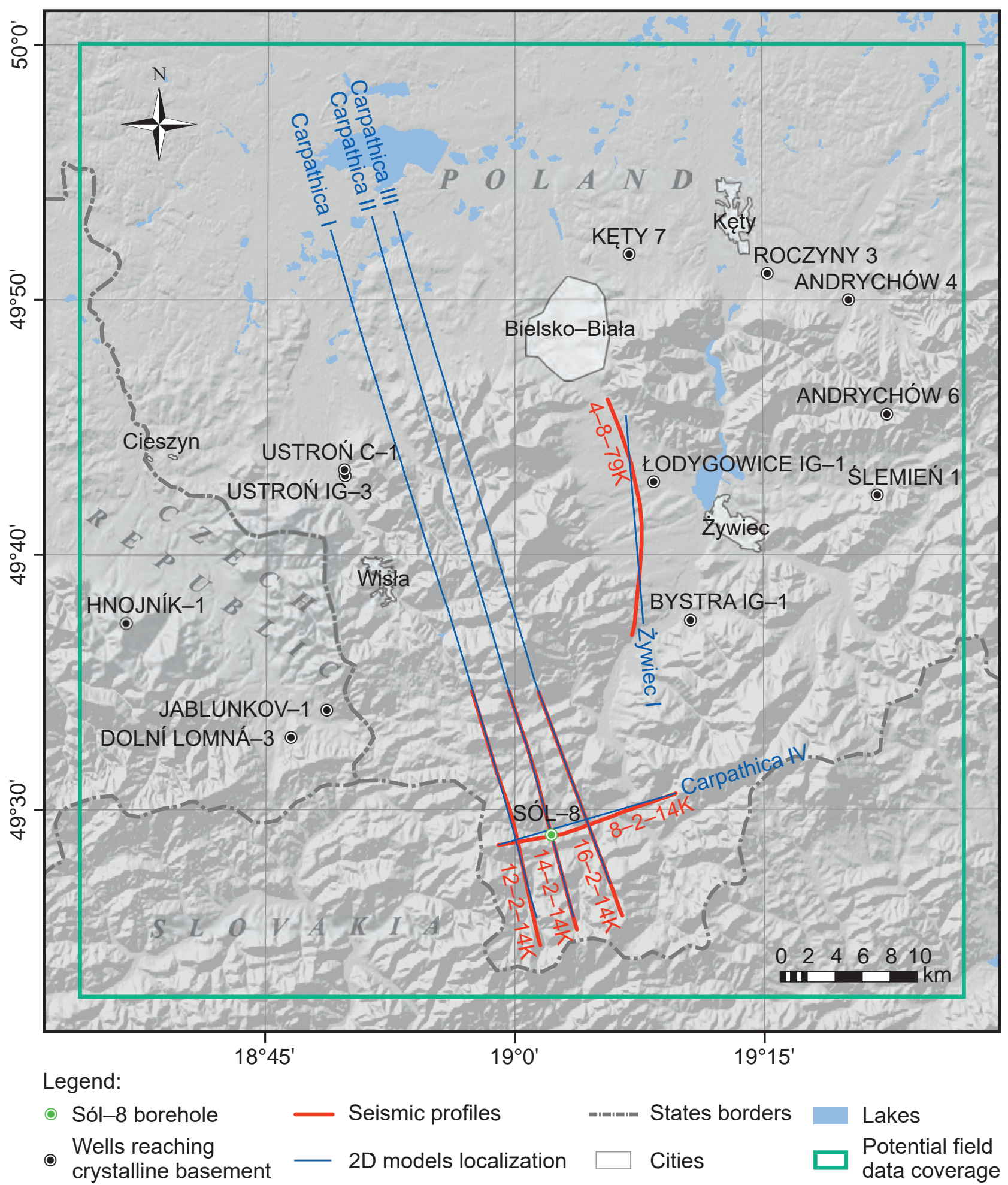

Fig. 3 Location of the seismic data and 2-D gravity and magnetic models on the background of topographical map.

IG-3, Kęty 7, Roczyny 3, Andrychów 4, Andrychów 6, Ślemień 1, Łodygowice IG-1, Bystra IG-1; Central Geological Database 2020) and Czech Republic (Dolní Lomná 3, Jablunkov 1, Hnojník 1; Picha et al. 2006) were used to constrain depth to the basement (Fig. 3).
Additionally, seismic data interpretation and gravity and magnetic forward modelling have been supported by several boreholes (e.g., Ustroń IG-2, Ustroń U-3A, Sól-8; Central Geological Database 2020), to constrain the structure and properties of the sedimentary cover. 


\section{Methods}

\subsection{Analysis of potential field data}

A number of transformations and derivatives of the gravity and magnetic data was produced for qualitative interpretation using a combination of Geosoft Oasis montaj ${ }^{\mathrm{TM}}$ and Getech's non-commercial software GETGrid. These enhancements were designed to boost the anomalies related to specific sources and filter out undesirable signals. Total horizontal derivatives (THD) enhance specific signatures of gravity and magnetic fields and associate them with corresponding geological structures. The first vertical derivative (1VD) sharpens up anomalies, permitting a better positioning of the causative structures (e.g., Blakely 1995). This derivative also amplifies short-wavelength anomalies produced by shallow sources. The second vertical derivative (2VD; Elkins 1951) provides further support in determining the edges of anomaly bodies. The 2VD is calculated solely for the high-resolution magnetic data from the Polish territory. The low-pass (LP) and high-pass (HP) filters eliminate wavelengths shorter and longer than a defined cut-off, respectively. The low-pass filters isolate the effect of regional structures, especially the configuration of the consolidated basement. The high-pass filters remove regional trends from the data, thus amplifying anomalies related to shallow density or susceptibility contrasts.

For quantitative analysis of potential field data, we used the Geosoft GM-SYS 2-D forward modelling package. The modelling technique allowed construction of the geological model based on seismic horizons and well-tops that defined geometric interfaces between geological bodies. Each of these bodies was represented by a closed polygon having a specific density ascribed. The gravity response of the model was forward calculated, using the technique described in Talwani and Ewing (1960). The outcome of the calculation was compared with the observed gravity data. Depending on the degree of match between the synthetic response and observed gravity curve, the starting model was interactively adjusted until an acceptable fit was achieved. The densities of model bodies were assigned at 2.45-2.59, 2.70, 2.90 and $3.30 \mathrm{~g} \cdot \mathrm{cm}^{-3}$ for sediments, upper crystalline crust, lower crust and upper mantle, respectively. The latter three are typical values used for cratonic areas (e.g., Maystrenko and Scheck-Wenderoth 2009, 2013; Mazur et al. 2016). The density of each sedimentary layer was fixed based on boreholes and literature data (e.g., Grabowska et al. 1998, 2011; Grabowska and Bojdys 2001; Bojdys et al. 2008).

\subsection{Joint inversion of gravity and depth measurements}

Joint inversion of the Bouguer gravity data and depth measurements was based on the spatial method by Barnes and Barraud (2012). The method applied combats the non-uniqueness of potential field modelling using a joint inversion of gravity data with independent depth measurements treated as an additional data set. The numerical algorithm iteratively inverts for a surface, which is here the geometric interface corresponding to the top of the crystalline basement. The basement body is defined in the model by a grid of rectangular prisms, having a fixed top and specific density assigned. Their bottom depths are adjusted during successive iterations to produce the inverted surface, whose geometry provides the best match between a synthetic and observed gravity signal. The well tops and 2-D horizons were considered depthto-basement estimates, representing a set of geological measurements that were integrated into the inversion algorithm together with the gravity data. This approach allows the surface to be adapted to this geological data rather than being constrained by them. Moreover, the algorithm allows to assign weights to individual sets of input data, so the inversion can be forced to honour one measurement more closely than others. In our study, depth-to-basement information is provided by borehole tops and 2-D forward gravity and magnetic models built upon several seismic sections (Fig. 3).

The gravitational acceleration $g$ at $P$ ( $P$ is the observation point located at $(x, y, z)$ and always outside of $\Omega$ area) describes formula 4.2.1,

$g(P)=-G \int_{\Omega} \rho(Q) \frac{\left(z-z^{\prime}\right)}{r^{3}} d v$,

where $G$ is Newton's gravitational constant, $\rho(Q)$ means density at point $Q\left(x^{\prime}, y^{\prime}, z^{\prime}\right)$ within $\Omega$, and $r$ is a vector directed from $Q$ to $P$. Considering the three-dimensional Cartesian coordinate system, formula (4.2.1) can be rewritten as,

$g(P)=-G \int_{z_{1}}^{z_{2}} \int_{y_{1}}^{y_{2}} \int_{x_{1}}^{x_{2}} \frac{\rho z}{\left(x^{2}+y^{2}+z^{2}\right)^{\frac{3}{2}}} d x d y d z$

If we assume that rectangular prisms, which divided research area, have a linear density distribution $\left(a_{0}+a_{1} z\right)$ in vertical, formula (4.2.2) evolve to,

$g(P)=-G \int_{z_{1}}^{z_{2}} \int_{y_{1}}^{y_{2}} \int_{x_{1}}^{x_{2}} \frac{\left(a_{0}+a_{1} z\right) z}{\left(x^{2}+y^{2}+z^{2}\right)^{\frac{3}{2}}} d x d y d z$ 

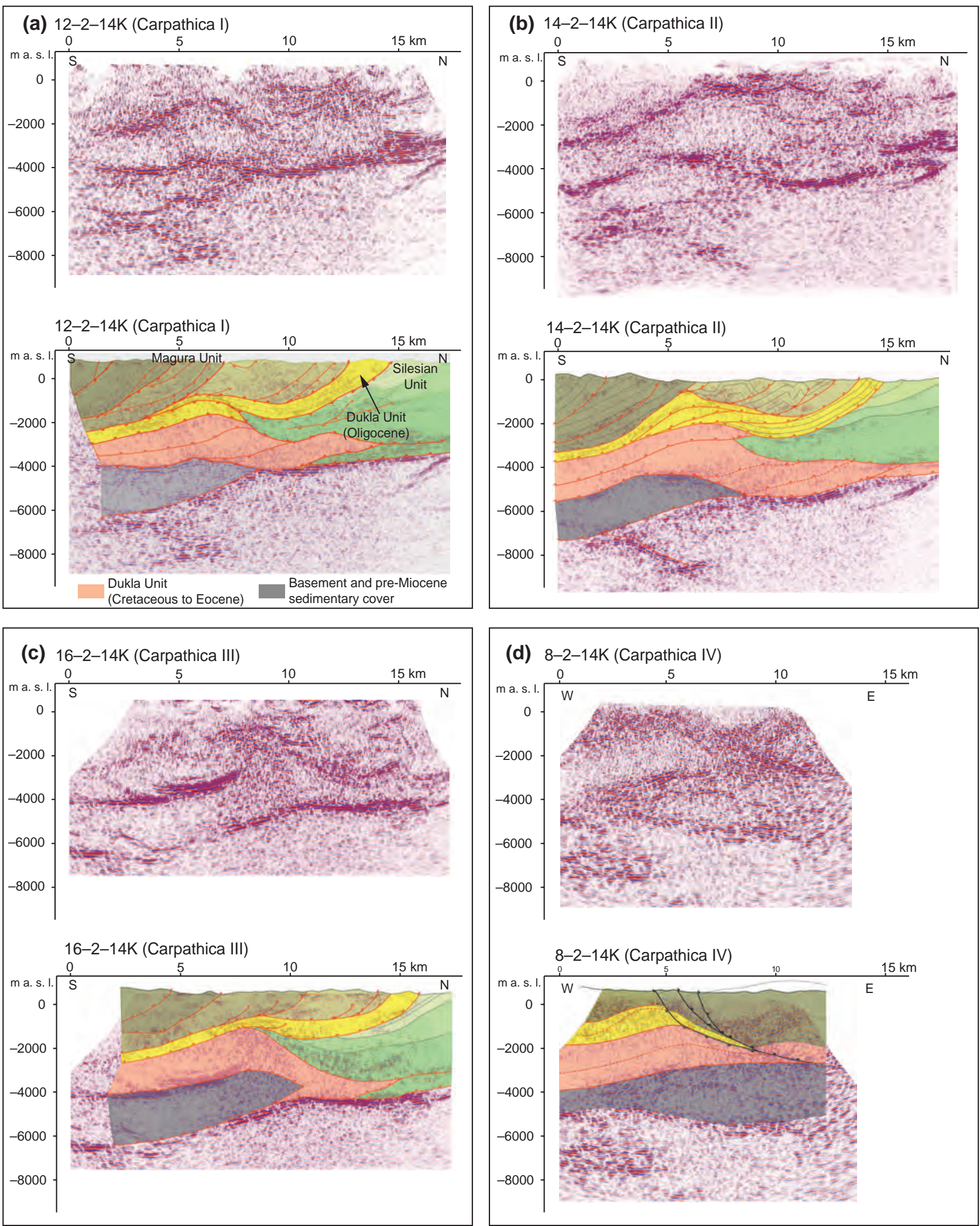

Fig. 4 Seismic data related to (a) Carpathica I, (b) Carphatica II, (c) Carpathica III, (d) Carpathica IV 2-D models. Upper and lower parts of each portion show un-interpreted and interpreted seismic profiles, respectively. 

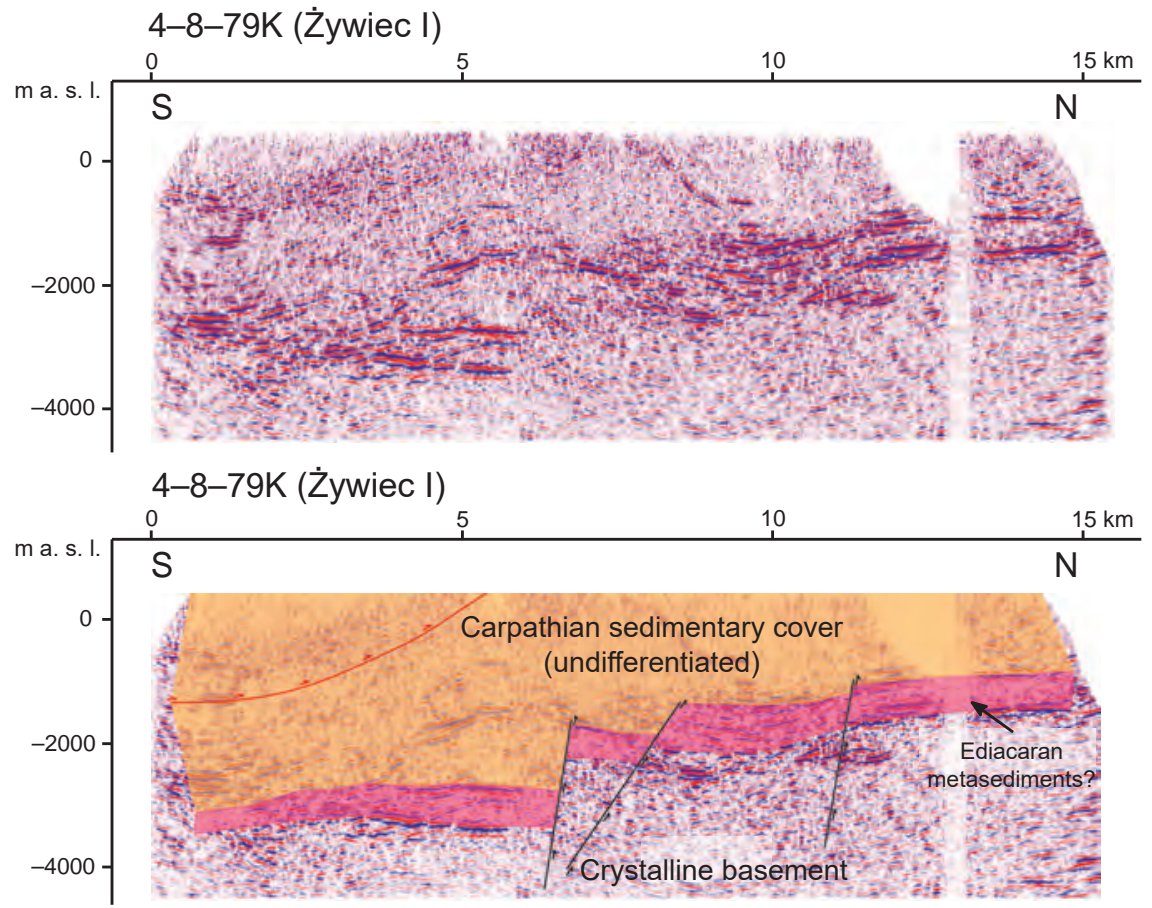

Fig. 5 Uninterpreted (upper part) and interpreted (lower part) 4-8-79K seismic profile corresponding to the Żywiec I 2-D model.
The first step in the workflow applied (Fig. 6) was to remove the effect of Moho morphology from the observed gravity signal. A two-layer model was created with the Moho horizon as an interface between the upper mantle and crust to achieve this goal. This approach was justified because the Moho discontinuity was reasonably well resolved by the seismic refraction data compiled in a gridded horizon by Majdański (2012). The upper mantle body had a flat base that was arbitrarily set at a depth of $60 \mathrm{~km}$. The top of the crustal body was defined by a digital elevation model. A density contrast of $0.35 \mathrm{~g} \cdot \mathrm{cm}^{-3}$ was adopted between the upper mantle and lower crust according to the results of deep refraction soundings (e.g., Grad et al. 2002; Guterch and Grad 2006). The synthetic response of the upper mantle body was afterwards subtracted from the observed gravity signal. The remaining residual anomaly

Tab. 2 Colour patterns for chronostratigraphic subdivisions used in the Carpathica I, II, III, IV models along with density and susceptibility values used

\begin{tabular}{|l|l|c|c|}
\hline Colour pattern & Layer/block & Density $\left[\mathbf{g} \cdot \mathbf{c m}^{-\mathbf{3}}\right.$ ] & Susceptibility (cgs) \\
\hline & $\begin{array}{l}\text { Magura Unit } \\
\text { (Cretaceous to Paleogene) }\end{array}$ & 2.53 & 0 \\
\hline & $\begin{array}{l}\text { Dukla Unit } \\
\text { (Lower Cretaceous to Paleogene) }\end{array}$ & $2.55-2.59$ & 0 \\
\hline & $\begin{array}{l}\text { Silesian Unit } \\
\text { (Upper Jurassic to Paleogene) }\end{array}$ & $2.55-2.57$ & 0 \\
\hline & Folded Miocene complex & 2.45 & 0 \\
\hline & Miocene (Foredeep) & 2.57 & 0 \\
\hline & Palaeozoic cover & 2.7 & $0.010-0.0255$ \\
\hline & Precambrian crystalline basement & 2.9 & 0 \\
\hline & Lower crust & 3.3 & 0 \\
\hline
\end{tabular}

was used in the following inversion exercise, assuming that it represents a gravity response of crustal sources.

The residual gravity anomaly was inverted for the top of the crystalline basement adopting a density contrast of $0.2 \mathrm{~g} \cdot \mathrm{cm}^{-3}$ between the crystalline crust and its sedimentary cover. For simplicity, no lateral density variation was assumed neither in the basement nor overlying sediments. The body representing a sedimentary cover was defined in a starting model by the flat top at a depth equal to a minimum topographic elevation and the base set at an arbitrary depth of $10 \mathrm{~km}$, exceeding the expected depth to basement. The inversion process was executed iteratively until an acceptable root-mean-square (RMS) deviation and convergence were attained.

All the uncertainty related to the time-to-depth conversion of seismic data as well as simplifications in the density structure of the $2-\mathrm{D}$ models must have deteriorated the fit between the observed and synthetic gravity profiles. However, the fit produced in our models with a mean error of $0.41-0.84$ $\mathrm{mGal}$ for gravity profiles is relatively low and demonstrates that a gravity response of the models is in the first instance controlled by the configuration of the basement. If the entire error is attributed to the top of the latter, that is only partly seismically controlled, the imperfection of 


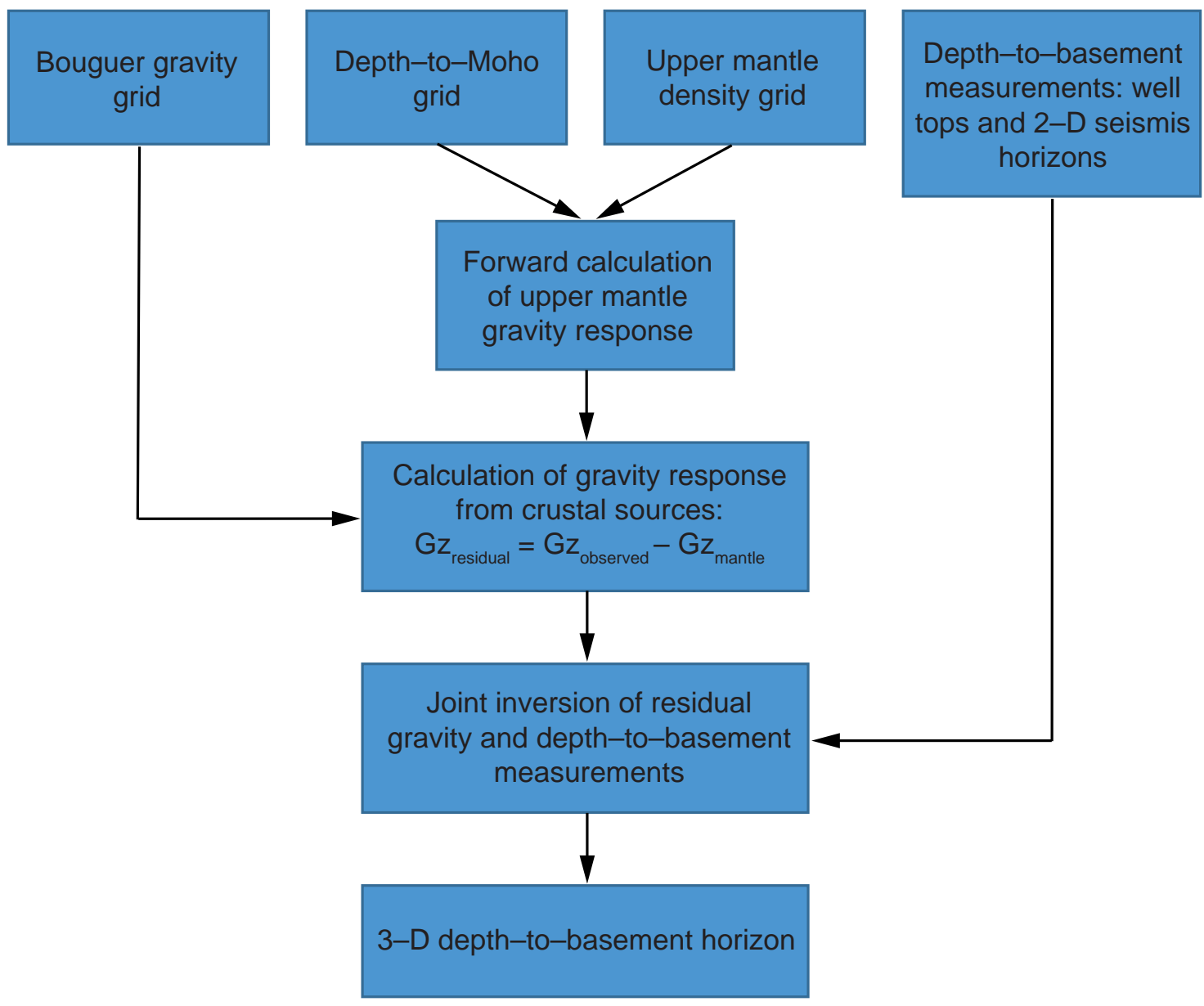

Fig. 6 Gravity inversion workflow diagram.

the gravity fit corresponds to a possible depth inaccuracy in the range of 200-400 $\mathrm{m}$. The correctness of the inversion procedure was controlled by the magnitude of a root-meansquare (RMS) deviation. The RMS error describing the fit of the modelled top of the basement does not exceed in our model a good value of $170 \mathrm{~m}$.

The algorithms applied, including the minimum curvature interpolation, smoothed the top of the basement grid, being an output of the inversion procedure. As a result, basement steps, potentially corresponding to faults, are mostly flattened. Therefore, the depth-to-basement grid was transformed into an isobath map using the results of structural mapping and the refinements produced by means of the 'spline with barriers' tool from ArcGISTM Spatial Analyst.

\section{Results}

\subsection{Qualitative interpretation}

The Bouguer gravity and RTP magnetic data (Fig. 2) and their derivatives, were applied to map the position of major structural elements in the study area. The ensuing set of structural elements was subsequently compared and calibrated with 2-D gravity models to create a consistent structural framework. The gravity and magnetic interpretation, presented in this section, is focused on understanding the geometry of the top of the crystalline basement and its interaction with the overlaying nappe units.

Bouguer anomaly maps (Figs. 2a and 7a) show a trend of decreasing gravity from $10 \mathrm{mGal}$ to $-66 \mathrm{mGal}$ towards $\mathrm{S}$ and SE. Some local gravity highs overprint this general slope and lows that are emphasized by the THD, 1VD and $20 \mathrm{~km}$ HP filter of Bouguer gravity (Fig. 7). The THD reveals strong linear anomalies (Fig. 7b) that can be considered the primary lateral density contrasts in the basement or sedimentary cover. Indeed, several lineaments in the Bouguer gravity derivative maps (Fig. 7) correlate with tectonic contacts between the major nappe units in the study area (Fig. 8). The best correlation is between the THD anomalies and the frontal thrusts of the Magura and Dukla Units. A good match also exists between the gravity anomalies and boundaries of tectonic windows as the Żywiec Window, where the Sub-Silesian Unit 

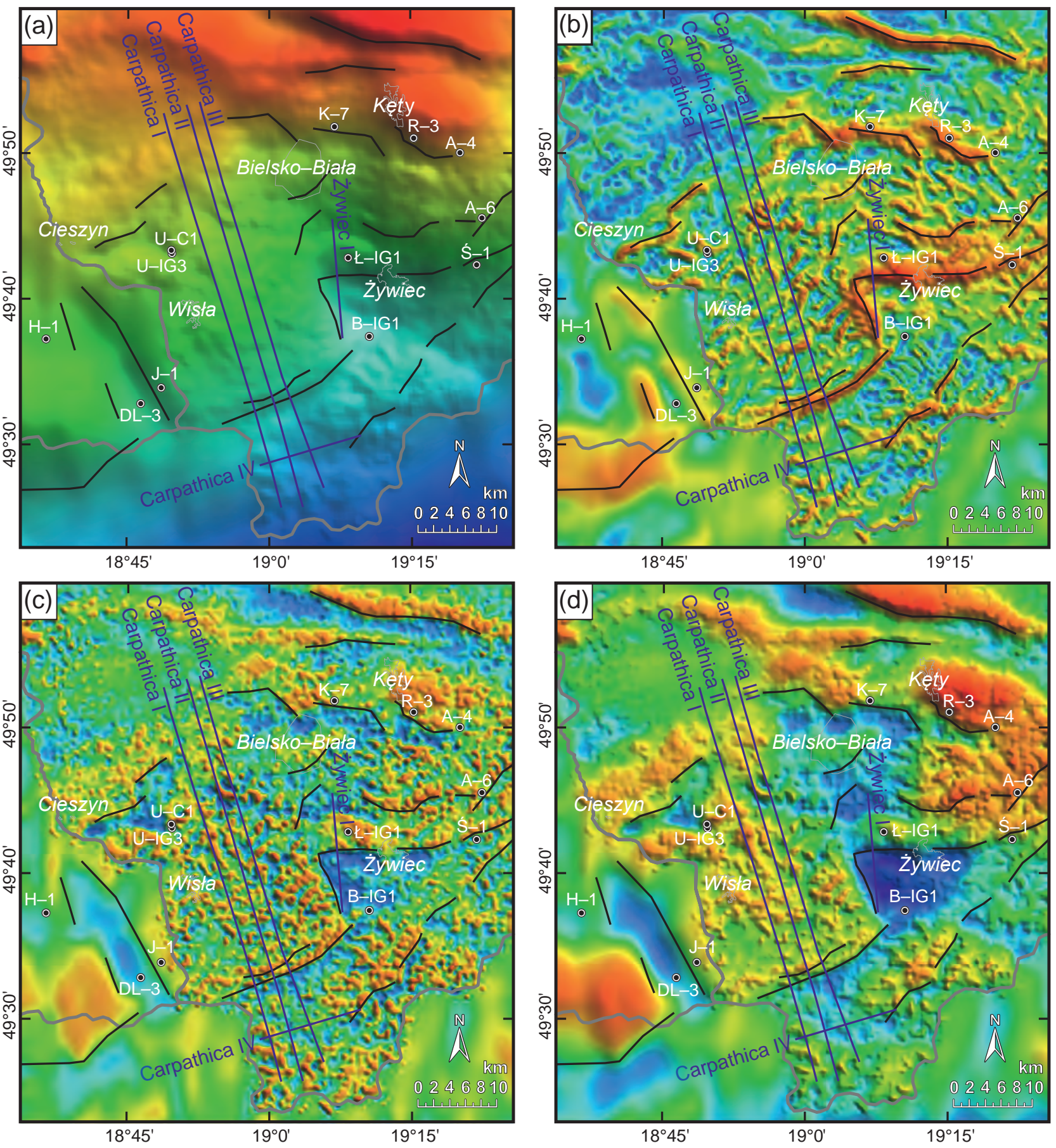

Legend:

Wells reaching
crystalline basement $\square$ Cities $\square$ States borders

Lineaments from gravity

2D models localization

Fig. 7 Qualitative interpretation of gravity data. Structural elements superimposed on (a) - the Bouguer gravity upper continued to $500 \mathrm{~m}$, (b) - the total horizontal derivative of the Bouguer gravity, (c) - the first vertical derivative of the Bouguer gravity, and (d) - the $20 \mathrm{~km}$ high pass filter of the Bouguer gravity. Boreholes abbreviations as in Fig. 2.

emerges from beneath the Silesian Unit (Fig. 8). Also, some coincidence is locally visible between the gravity lineaments and the frontal thrusts of the Sub-Silesian and Silesian Units as well as the internal thrust within the Ma- gura Unit. Finally, some gravimetric lineaments probably represent subsurface faults or density contrasts that are unrelated to known tectonic structures. Characteristically, the 1VD of Bouguer gravity consistently shows maxima 


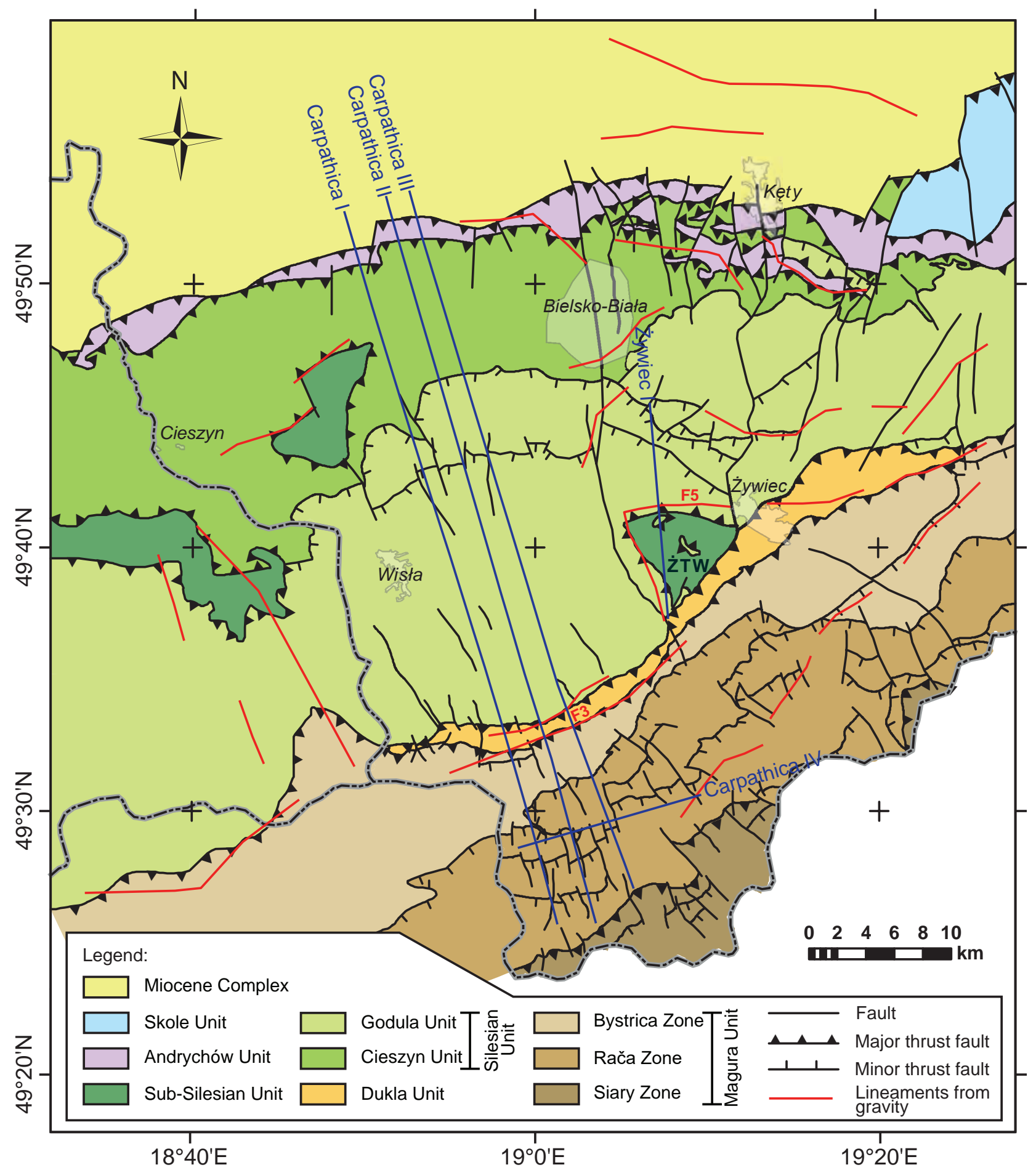

Fig. 8 Gravity lineaments superimposed on a geological map.

directly north of the THD lineaments (Figs $7 \mathrm{~b}$ and 7c), suggesting northward uplift of possible foot walls. This observation is strengthened by $20 \mathrm{~km}$ HP filter of Bouguer gravity that reveals gravity highs on the northern side of the THD lineaments (Fig. 7d). Since $20 \mathrm{~km} \mathrm{HP}$ filter emphasizes anomalies from sources shallower than
5-7 km the structure of the basement probably has a significant impact on the anomaly pattern of filtered gravity.

The Reduced-to-Pole (RTP) magnetic data are characterized by a large magnetic low in the centre of the studied area, the Bielsko-Biała (B-B) low that shows RTP values down to $-78 \mathrm{nT}$ (Figs $2 \mathrm{~b}$ and $9 \mathrm{a}$ ). The in- 

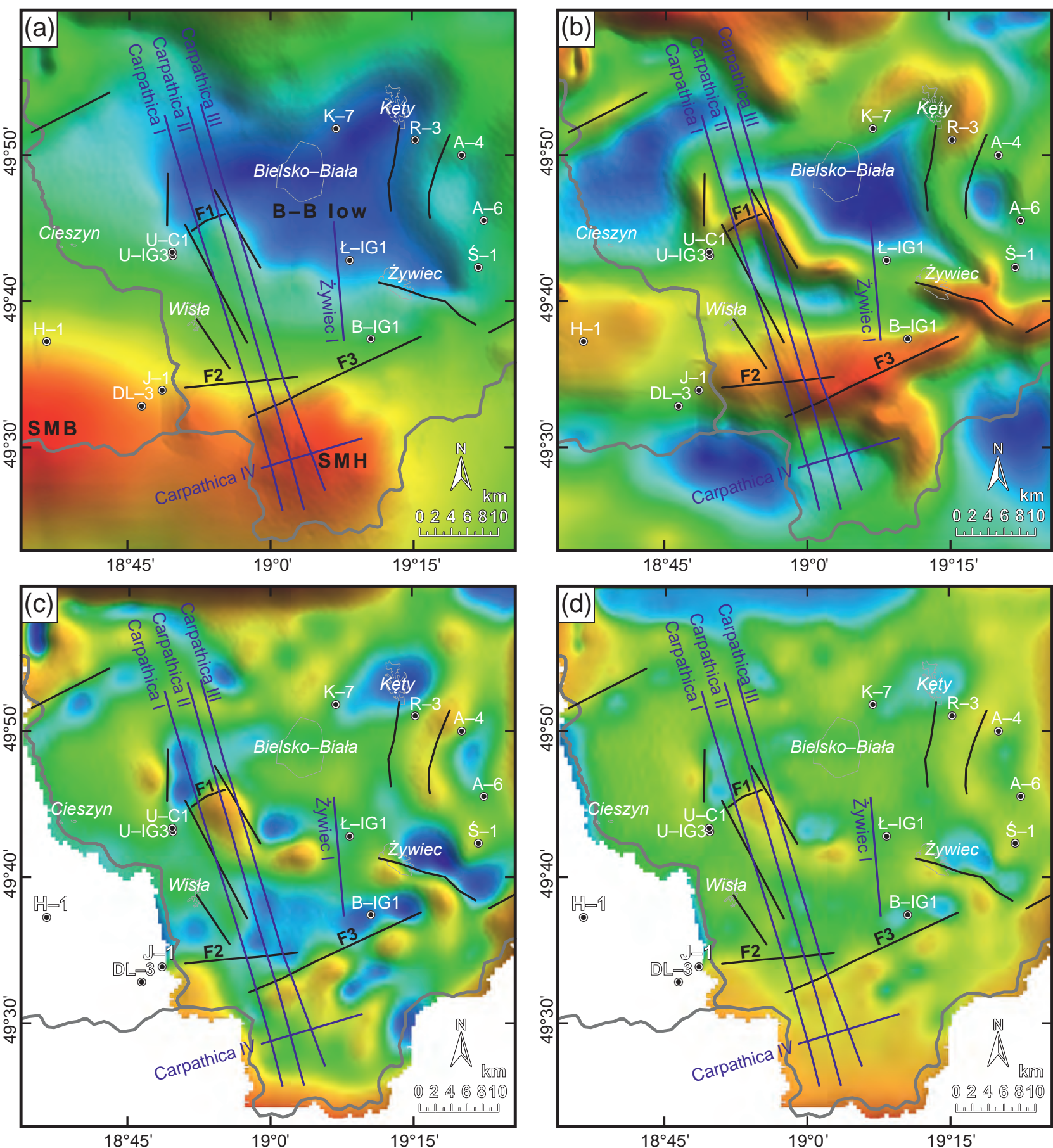

Legend:

Wells reaching
crystalline basement Cities States borders Lineaments from magnetic 2D models localization

Fig. 9 Qualitative interpretation of magnetic data. Structural elements superimposed on (a) - Reduce-to-Pole (RTP) magnetic anomaly map, (b) - Total Horizontal Derivative (THD) of the RTP data, (c) - First Vertical Derivative (1VD) of the RTP magnetic data, and (d) - Second Vertical Derivative (2VD) of the RTP magnetic data. Derivatives (b), (c) and (d) are low pass filtered with a cut-off wavelength of $10 \mathrm{~km}$. Vertical derivatives are calculated for the territory of Poland owing to the better resolution of magnetic data from this area. Boreholes abbreviations as in Fig. 2.

creased magnetization towards the $\mathrm{N}$ is associated with the uplift of the crystalline basement, the observation is confirmed by borehole data (Buła and Habryn 2008,
2011). The reason for the presence of a magnetic high in the $\mathrm{S}$ (74 nT) is more complex than it seems. The anticorrelation between gravity and magnetic data in this area 

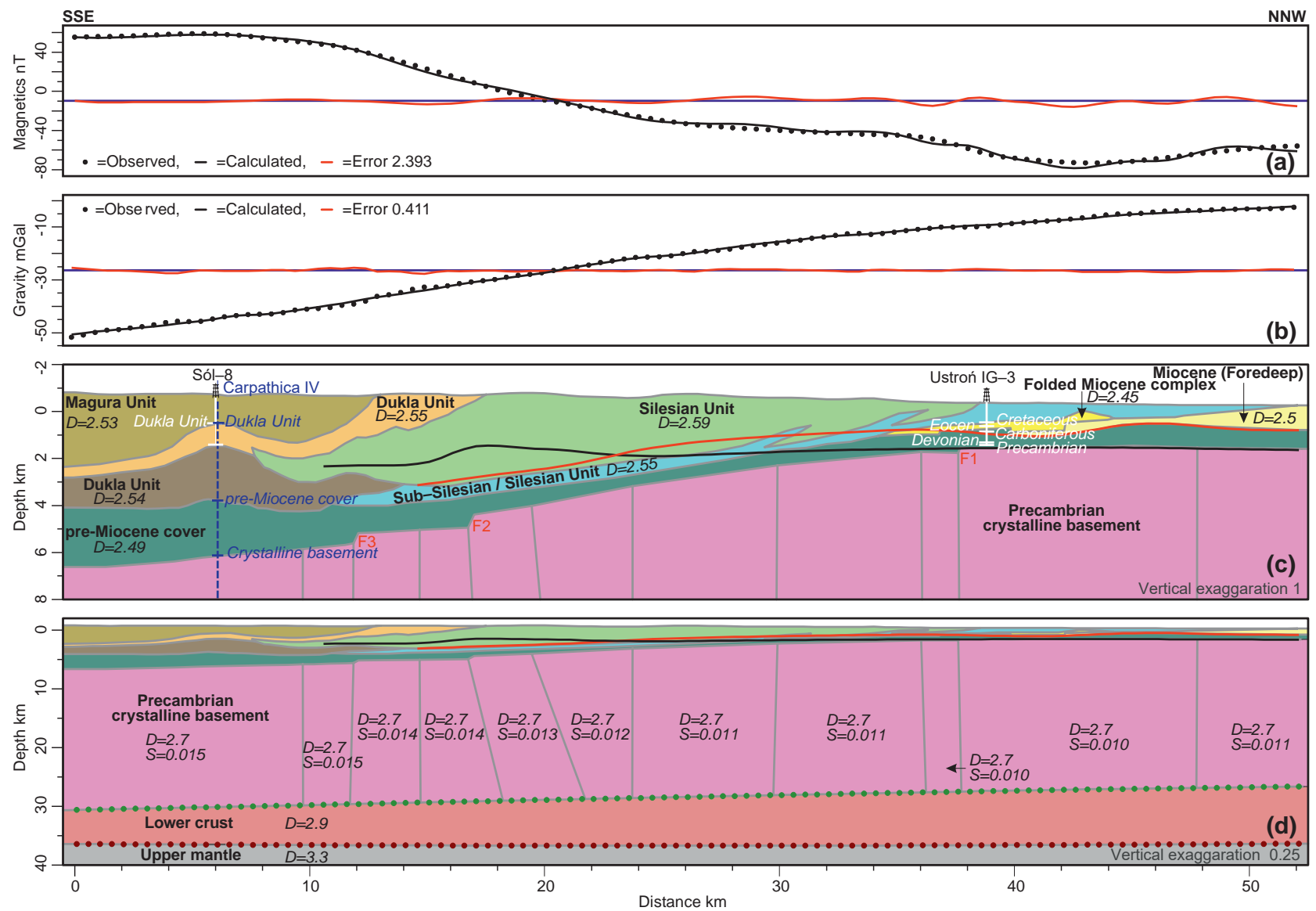

Fig. 10 Model Carpathica I. (a), (b) -magnetic and gravity profiles, respectively. Dotted and solid black lines indicate observed and modelled data. Red hairline means a magnitude of the error. (c), (d) -the upper section of the geological model and a full geological model, respectively. $D$ means density in $\mathrm{g} \mathrm{cm}^{-3}$ and $S$ is susceptibility. Red labels "F1", "F2" and "F3" indicate basement-rooted faults. Black and bold red lines represent the top of the consolidated basement from Paul et al. (1996) and the top of pre-Permian Palaeozoic or Precambrian basement after Buła and Habryn (2008), respectively. Green and burgundy dots denote the lower crust and Moho horizons that were derived from Majdański (2012).

is related to the crystalline basement's lithological variability rather than a depth to magnetic sources. East of the B-B low, mafic rocks, as well as siderites, were found in boreholes Andrychów 4, Andrychów 6 and Ślemień 1, which penetrated the basement (Tab. 1). These rocks are characterized by increased magnetic susceptibility relative to granites and gneisses underneath the B-B low (e.g., Łodygowice IG-1 and Kęty 7 wells, Tab. 1).

The magnetic high south of the B-B low (Figs 2b and 9a), hereafter referred to as the Sól magnetic high (SMH), is part of a large positive magnetic anomaly, extending from Poland through the Czech Republic to Austria and defined by Dědáček et al. (1997) as the South MoravianBeskydy (SMB) regional magnetic anomaly. As seen from our merged magnetic data set, the SMB anomaly continues eastwards into the Polish territory, corresponding to the SMH (Figs 2b, 9a). The SMB magnetic high source within its Czech section is linked by Gnojek and Hubatka (2001) to the occurrence of intermediate to mafic plutonic rocks in the basement. The same explanation might also be applicable to the SMH in Poland, the east- ernmost part of the SMB magnetic high, the hypothesis that requires further testing through quantitative modelling. The tests (see below) are based on the assumption that susceptibility of sedimentary rocks in the western Carpathians is practically negligible (Gnojek and Hubatka 2001 and references therein). There is no information available from the study area and its neighbourhood on the occurrence of upper Palaeozoic volcanic rocks that could have contributed to the magnetic response of the crystalline basement.

The THD derivative of the RTP data highlights some magnetic lineaments in the study area (Fig. 9b) that reflect a susceptibility structure of the crystalline basement. The most important of them (F2 and F3) corresponds to the northern boundary of the SMH (Fig. 9). However, based on qualitative analysis, it is impossible to reveal whether they represent a tectonic contact within the crystalline basement, a basement step, or an intrusive complex boundary. A regular linear trend of the SMB magnetic high may suggest a correlation with a tectonic boundary. In contrast, an oval shape of the B-B low implies a 

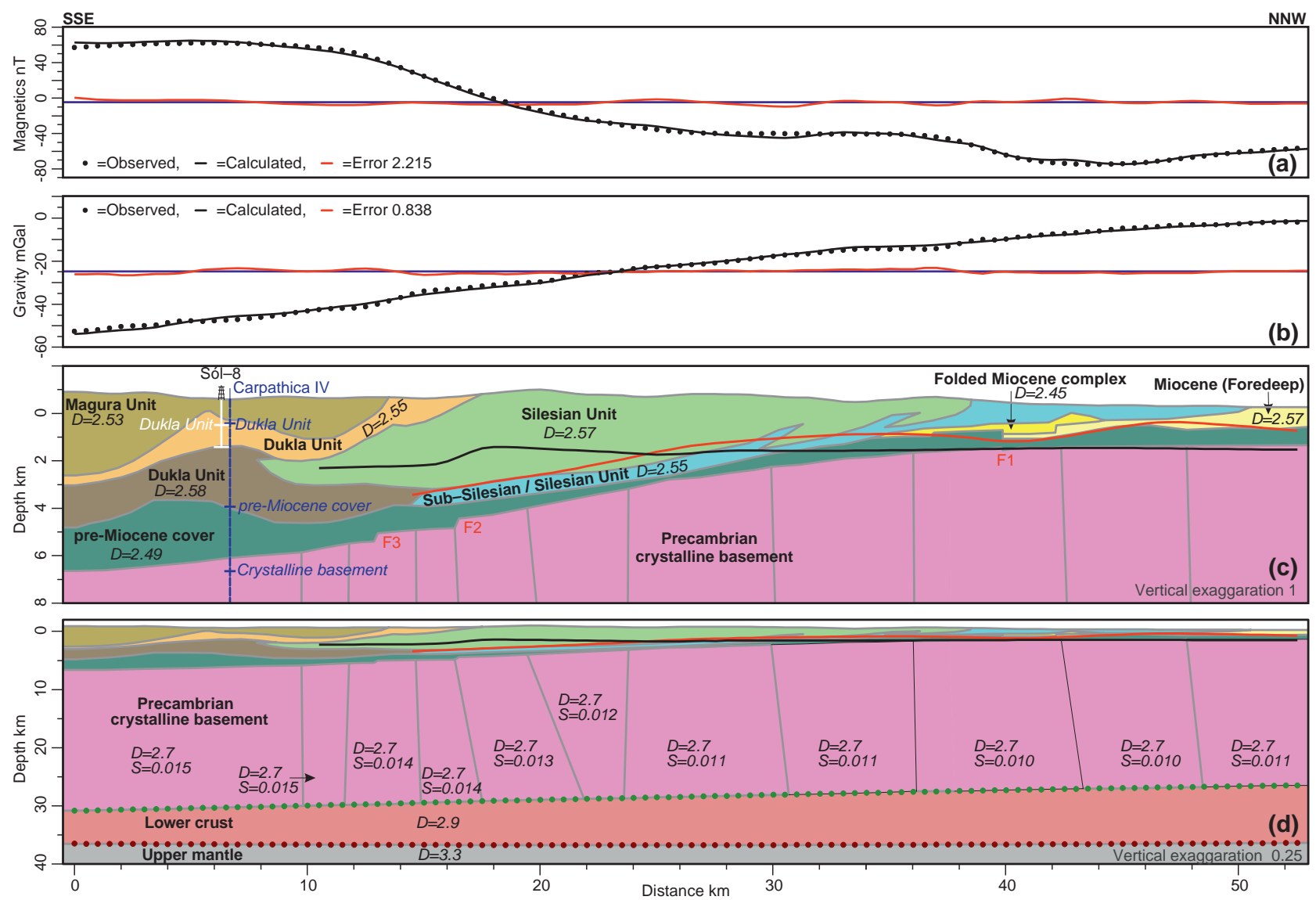

Fig. 11 Model Carpathica II. Designations and abbreviations as described in the caption of Fig. 10.

connection with an igneous complex. Vertical derivatives of the RTP magnetic data (Fig. 9c, d) emphasize some NNW-SSE oriented faults that are poorly imaged in the 2D gravity and magnetic models due to their subparallel orientation. These faults are oblique at a high angle to the boundaries of the SMH but are parallel to important faults revealed by the gravity and well data in the Czech Republic, directly west of the Polish border (Fig. 7).

\subsection{2-D gravity and magnetic forward modelling}

Among five 2D forward models that have been built, three (Carpathica I, II, and III) are located in the western part of the study area and run almost parallel to each other in general direction NNW-SSE (e.g., Fig. 3). Carpathica I represents the same model earlier presented by Barmuta et al. (2019) under the name Carpathica 2018. Fourth model, Carpathica IV, runs perpendicular to the previous three in their southern part and acts as a tie line. The last model, Żywiec I, is oriented N-S and crosses the northern boundary of the Żywiec Window.

The 2D models include four main layers: the upper mantle, lower crust, Precambrian crystalline basement and sedimentary cover. The Moho surface and top of the lower crust were extracted from the grids calculated by Majdański (2012). In each model, the Moho and top of lower crust run almost horizontally at a depth of 36 and 30 km, respectively (Figs 10-14). Both horizons are generally flat and smooth. The Carpathian sedimentary cover is divided into smaller layers representing pre-Miocene autochthonous sediments and Carpathians nappes based on seismic reflection profiles. For the upper mantle, lower crust and Precambrian crystalline basement, we adopted densities of 3.3, 2.9 and $2.7 \mathrm{~g} \cdot \mathrm{cm}^{-3}$, respectively (Tab. 2). These values are based on average P-wave velocities from combined seismic refraction studies (Majdański 2012) that were recalculated to density using the NafeDrake formula. The density values were assigned to individual sedimentary layers relay on borehole data, seismic interval velocities from refraction profiles and information acquired from the literature (e.g., Grabowska et al. 2007; Bojdys et al. 2008). Since the top of the crystalline basement is poorly constrained by the seismic reflection lines, this horizon remains the main unknown in the course of the modelling exercise.

The Carpathica I, II and III models (Figs 10, 11 and 12) run relatively close to each other and show mutual 

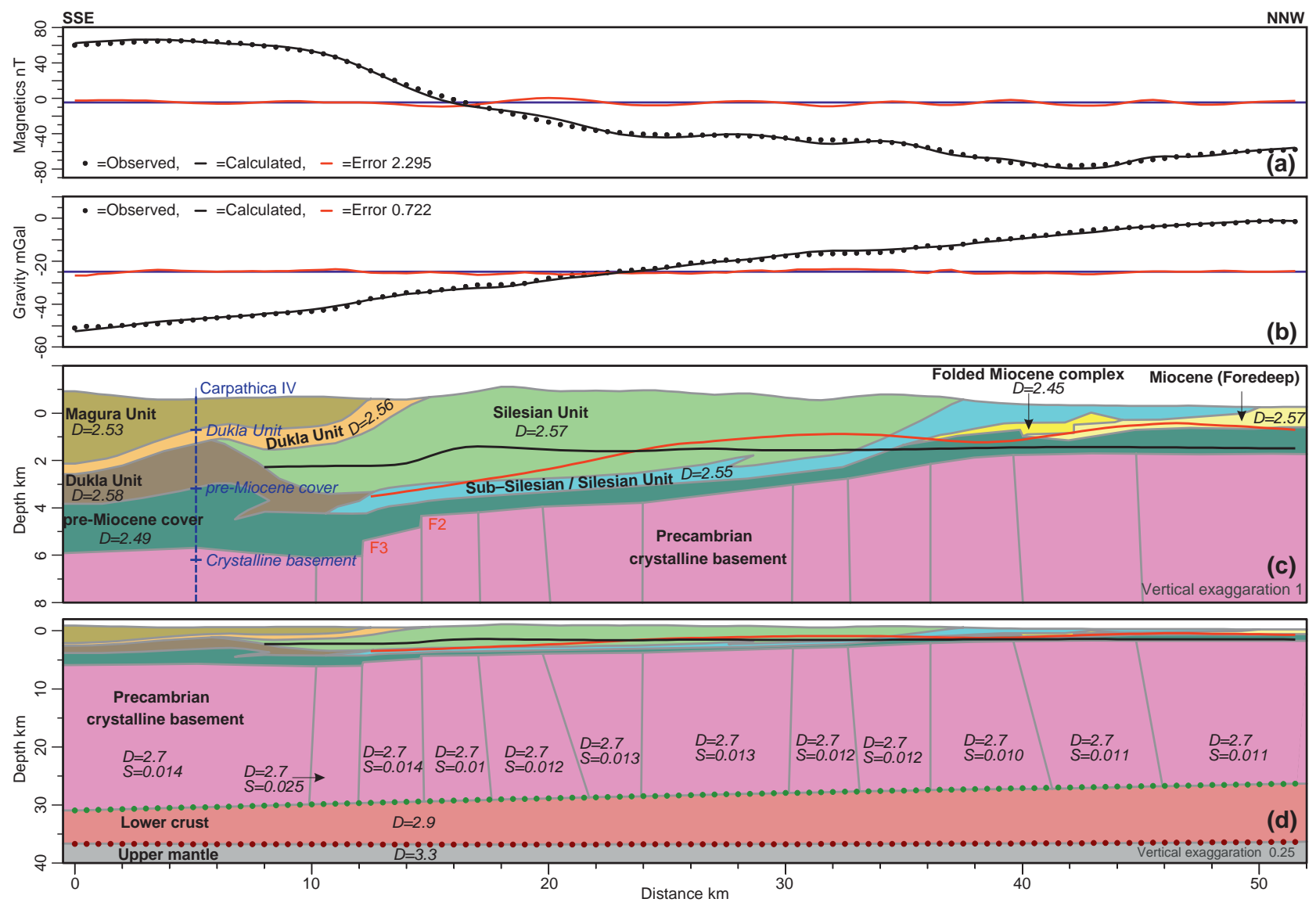

Fig. 12 Model Carpathica III. Designations and abbreviations as described in the caption of Fig. 10.

correlation. In sedimentary cover, all layers have similar densities in the range of 2.45 to $2.59 \mathrm{~g} \cdot \mathrm{cm}^{-3}$ with the lowest value corresponding to the folded Miocene complex and the highest assigned to a part of the Dukla Unit (Tab. 2). The Bouguer anomaly for the Carpathica I profile is in the interval of -54.22 to $-0.20 \mathrm{mGal}$ and decreases southward. To achieve a good match between the observed gravity data and the model's synthetic response (mean error $0.411 \mathrm{mGal}$ ), it was necessary to lower the top of the crystalline basement toward the south (Fig. 10). Consequently, the crystalline basement with a density of $2.7 \mathrm{~g} \cdot \mathrm{cm}^{-3}$ was replaced with less dense pre-Miocene autochthonous sediments $\left(2.49 \mathrm{~g} \cdot \mathrm{cm}^{-3}\right)$. The Carpathica II, III models show the similar top basement configuration that allows for fitting of the 'models' response to the observed gravity profiles (Fig. 11, 12). Therefore, all three models (Carpathica I, II, III) reveal a relatively thick pile of pre-Miocene sediments underneath the Carpathian nappes that are sufficiently imaged by the seismic data (Fig. 4).

The depth to the crystalline basement in the Carpathica I, II, III models increases southward in the range of 1 400-6 700, 1 350-6 650 and 1 700-6 060 m b. s. l., respectively (Figs 10-12). In the latter model, the top of basement rises again by about $430 \mathrm{~m}$ at the intersection with the Carpathica IV model (Fig. 13). Three normal faults (basement steps) F1, F2, and F3 are suggested in the Carpathica I model by magnetic data (Fig. 9). Vertical displacements on these faults are $480 \mathrm{~m}, 550 \mathrm{~m}$ and $300 \mathrm{~m}$, respectively. These basement faults are related to the position of the Magura, Dukla and Silesian frontal thrusts, imaged by seismic data. Faults F3 and F2 continue and are visible into the two next models, Carpathica II and III. The basement along the Carpathica II profile is shifted upward with respect to the neighbouring Carpathica I and III sections, forming an NNW-SSE elongated ridge. The existence of this ridge is supported by the NNW-SSE oriented discontinuities (possible normal faults) that are revealed by the $1 \mathrm{VD}$ and $2 \mathrm{VD}$ of the RTP magnetic data (Fig. 9c, d).

The general southward slope of the crystalline basement in the Carpathica I, II, III models is consistent with a shape of magnetic profiles (Fig. 10-12). The intensity of the RTP magnetic field decreases toward the SSE from about $65.86 \mathrm{nT}$ (recorded in Carpathica I) to $-86.54 \mathrm{nT}$ (recorded in Carpathica III). Nevertheless, a variable susceptibility in the relatively narrow range (0.01 to 0.015) was applied to improve the match between the 

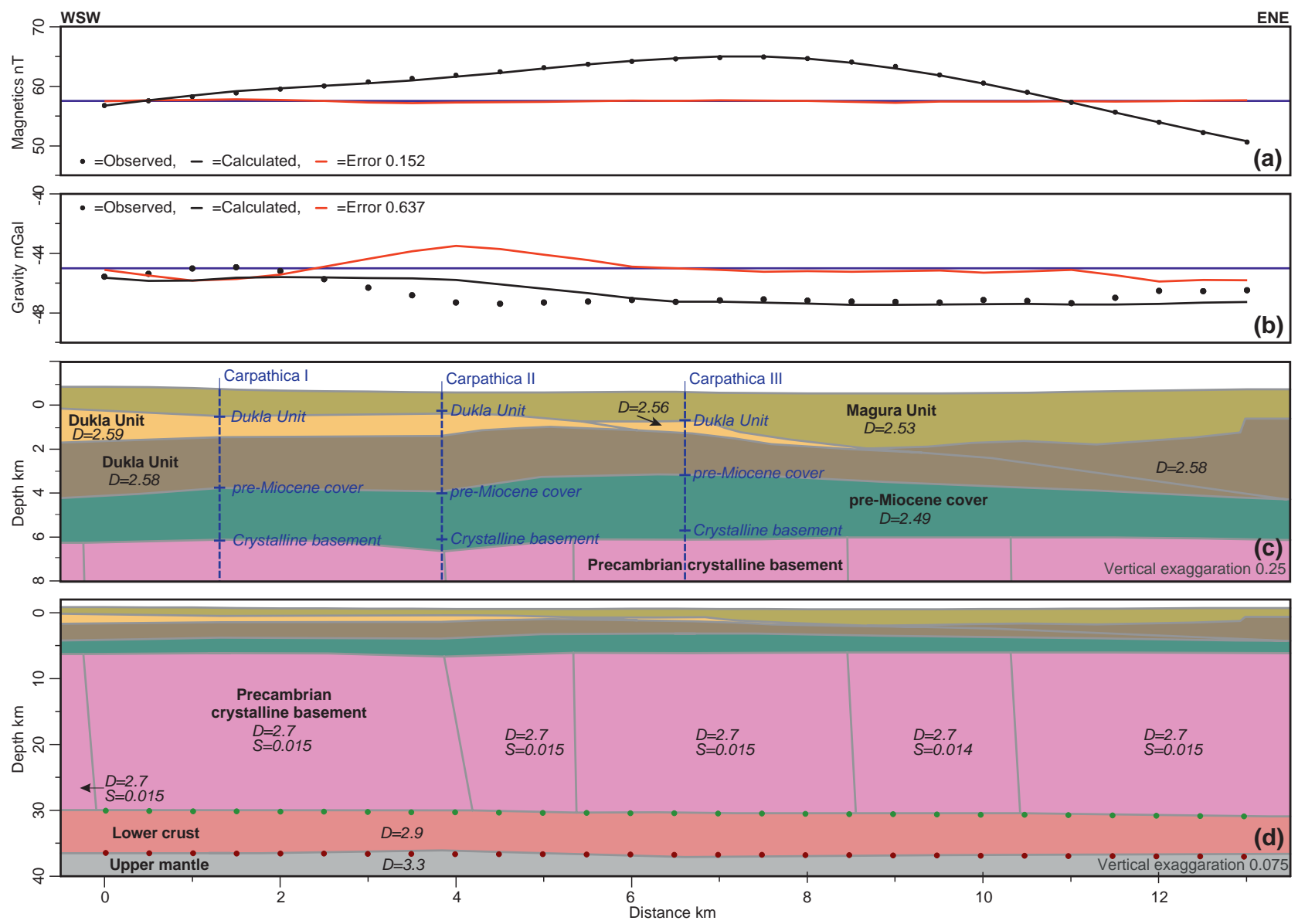

Fig. 13 Model Carpathica IV. Designations and abbreviations as described in the caption of Fig. 10.

observed and synthetic magnetic profiles and retain the top of basement geometry that also fit gravity data. This was expected that susceptibility of the crystalline basement is laterally more variable than its density. With some exceptions, models Carpathica I, II, III demonstrate the southward increase of susceptibility that may have implications for basement lithology.

The Carpathica IV model (Fig. 13) is a tie line for models Carpathica I, II and III oriented approximately along strike of main thrusts and the basement slope. In this case, the RTP magnetic field variability, ranging from 49.90 to $65.73 \mathrm{nT}$, and the Bouguer gravity, varying between -47.78 to $-44.79 \mathrm{mGal}$, is insignificant. The model shows a good match both to the observed gravity

Tab. 3 Colour patterns for stratigraphic subdivisions used in the Żywiec I model along with density and susceptibility values used

\begin{tabular}{|l|l|c|c|}
\hline Colour pattern & Layer/block & Density $\left[\mathbf{g} \cdot \mathbf{c m}^{-3}\right.$ ] & Susceptibility (cgs) \\
\hline & $\begin{array}{l}\text { Carpathian sedimentary cover } \\
\text { (Palaeozoic, Jurassic, Cretaceous) }\end{array}$ & $2.5-2.56$ & 0 \\
\hline & Precambrian crystalline basement & 2.7 & $0.0086-0.17$ \\
\hline & Lower crust & 2.9 & 0 \\
\hline & Upper mantle & 3.3 & 0 \\
\hline
\end{tabular}

and magnetic data and intersections with the Carpathica I-III models.

Due to the complex geology and insufficient quality of seismic data, separating of the sedimentary cover into individual tectonic or chronostratigraphic units was not feasible for the Żywiec I model (Fig. 14). Instead, we divided the sediments into some layers characterized by discrete density values in the range of 2.50 to 2.56 $\mathrm{g} \cdot \mathrm{cm}^{-3}$ (Tab. 3). Notably, the highest densities are in the northern part of the model and decrease southward. The crystalline basement generally dips southward from 1350 to $3500 \mathrm{~m} \mathrm{~b}$. s. l. and rises at the southern end of the model by about $500 \mathrm{~m}$. The latter is confirmed by the Bystra IG-1 borehole, which encountered the crystalline basement at a depth of 3132 $\mathrm{m}$ b. s. 1. The magnetic profile revealed the presence of three faults displacing the crystalline basement. These faults, designated as F4, F5 and F6 in Fig. 14 , are characterized by large displacements of 470, 960 and $840 \mathrm{~m}$, respectively. 

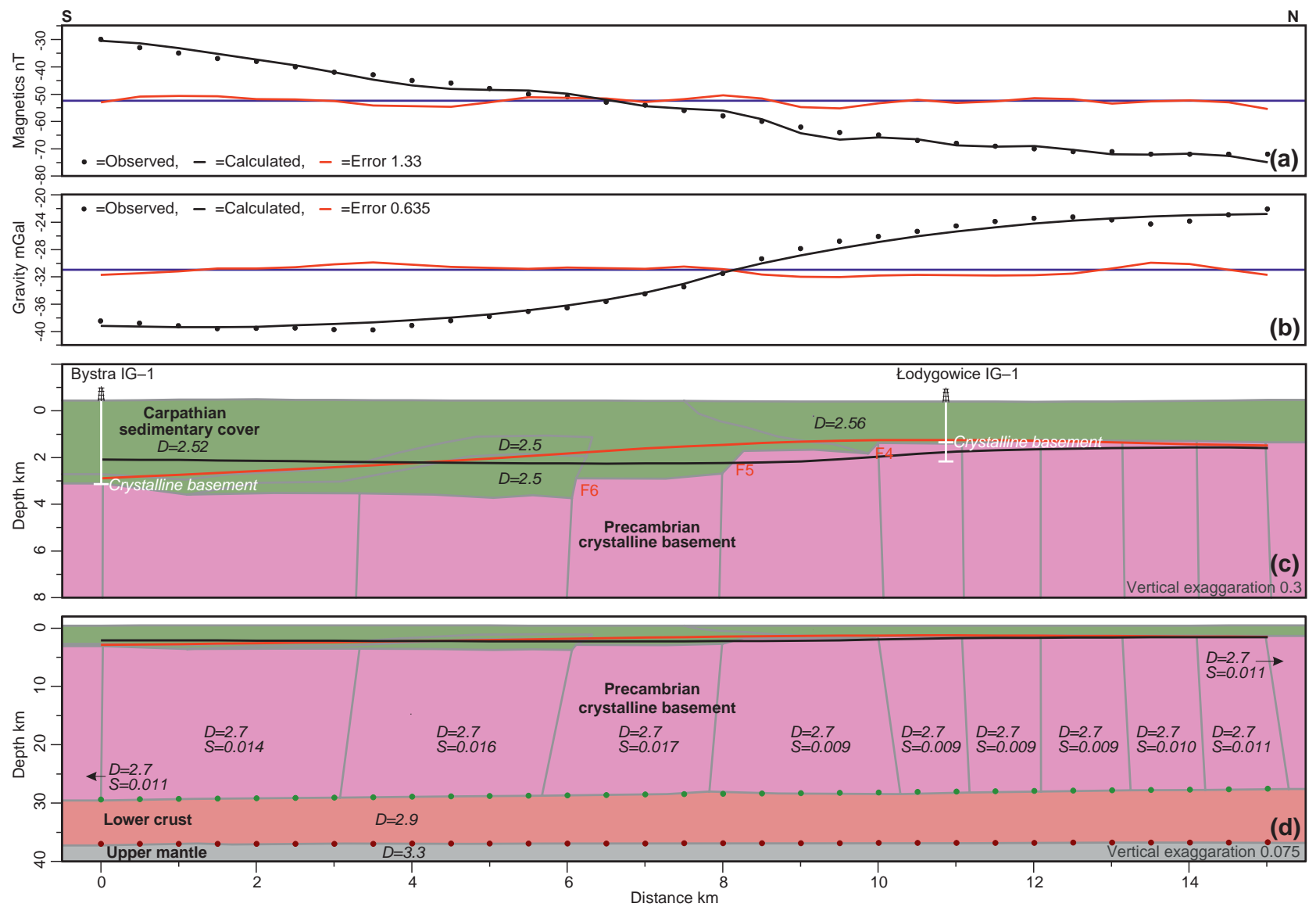

Fig. 14 Model Żywiec I. Red labels "F4", "F5" and "F6" indicate basement-rooted faults. Other designations and abbreviations in section (a), (b), (c) and (d) as described in the caption of Fig. 10.

\subsection{3-D joint inversion of gravity results}

The grid derived from 3-D gravity inversion shows a regional slope of the top of basement toward the south by c. $5000 \mathrm{~m}$ (Fig. 15). Some roughness is related to well tops and 2-D horizons from the gravity and magnetic models owing to a relatively large weight attributed to these measurements in the course of modelling. The depth-tobasement in the southern part of the study area is almost 7000 meters b. s. l., while in the north it approaches 1000 meters b. s. l. The basement deepening at a distance of $70 \mathrm{~km}$ corresponds to about $5^{\circ}$ slope, representing a ramp during the emplacement of the Carpathian nappes. Since inverse modelling is a geophysical approximation of the real geological structure its results must be supplemented with all available geological information.

\subsection{Integration of inversion results and structural interpretation}

The top of the basement grid was integrated with the results of qualitative interpretation of magnetic data to produce a geological depth-to-basement map (Fig. 16).
The 'spline with barriers' tool (from ArcGIS' ${ }^{\mathrm{TM}}$ Spatial Analyst) allowed to recreate the subordinate basement steps associated with basement faults that had been smoothed out by a gridding algorithm. Considering a gravity grid pitch, none of the basement faults exceeds $500 \mathrm{~m}$ of vertical separation that is consistent with the results of 2D forward modelling (Figs 10-14). The obtained map reflects the more realistic architecture of the crystalline basement than a purely geophysical grid (Fig. 15).

\section{Geological implications}

The 2-D modelling demonstrates that the geometry of the basement controls the gravimetric and magnetic fields. Contribution of intra-sedimentary sources is insignificant. Therefore, geological consequences of the gravimetricmagnetic analysis refer in principle to the geometry and composition of the sub-Outer Carpathian basement.

The depth to basement derived from the gravity inversion is deeper than presented in previous basement maps (Paul et al. 1996; Grabowska et al. 1998; Buła and Habryn 2008). In the northern part of the study area, where 


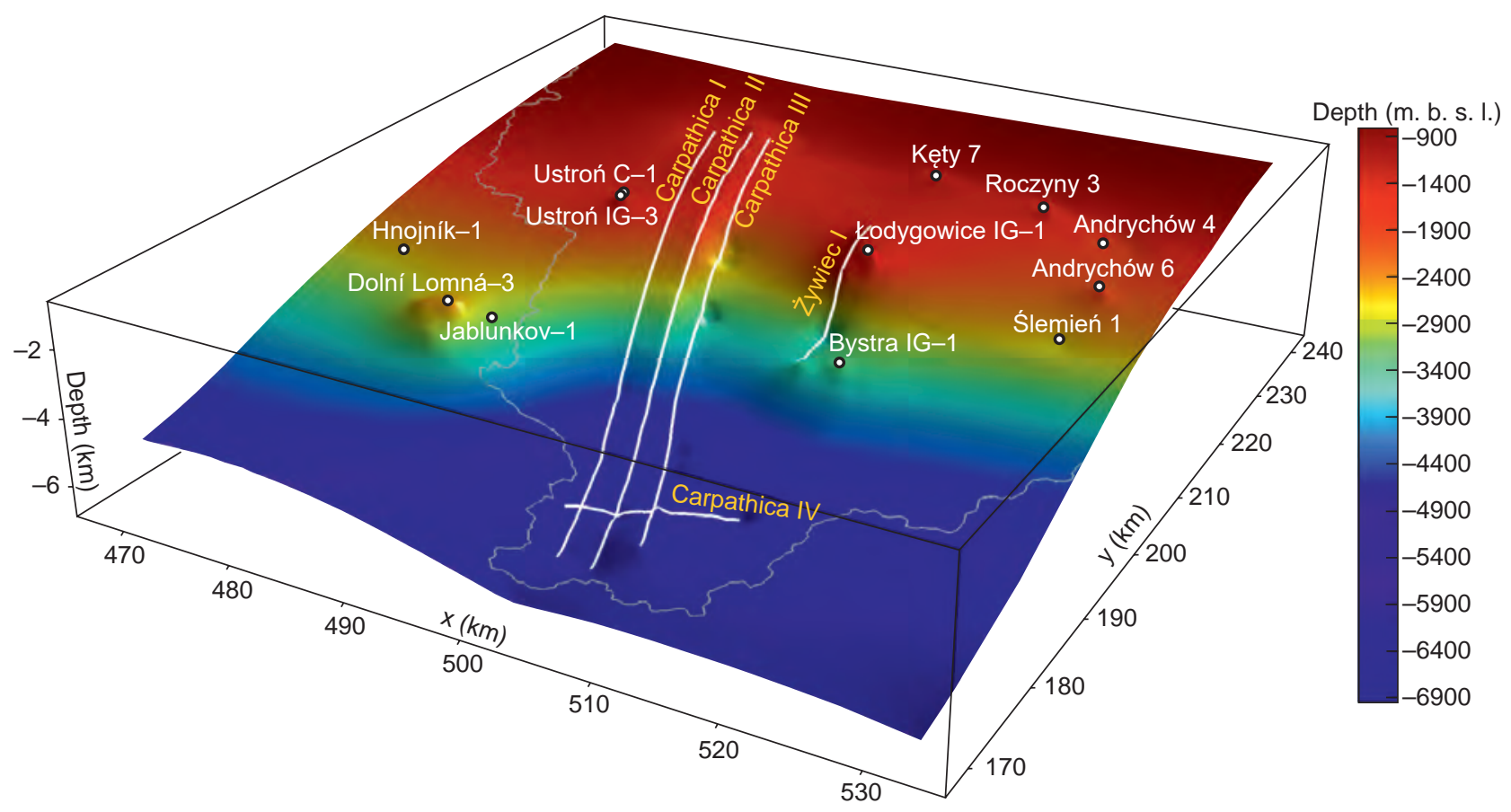

Fig. 15 Perspective view of the depth to crystalline basement derived from 3-D joint inversion of gravity, borehole data and horizons from the 2-D forward models.

the shallow Precambrian basement is well constrained by borehole data, all interpretations are relatively close (Figs 10-14). Further south, the top of the basement by Paul et al. (1996) and Buła and Habryn (2008) is c. $2000 \mathrm{~m}$ shallower than the modelled one and often close to the top of autochthonous pre-Miocene sediments in our sections. The mechanical basement of the Outer Carpathian fold-and-thrust belt has been hence previously treated as the crystalline basement proper. Our study further confirms a purely thin-skinned deformation style of the Outer Carpathian orogenic wedge, without any basement involvement at least up to the central part of the Magura Unit (Oszczypko 2006; Gągała et al. 2012). Basement steps derived from the 2-D modelling seem to represent orogen-ward dipping normal faults related to flexural bending of the foreland plate. Potentially similar structures have been described from the Outer Carpathian foreland basin in eastern Poland by Krzywiec (2001) and Krzywiec et al. (2014).

Age and lithology of the pre-Miocene layer are not constrained. Although boreholes tested Palaeozoic strata in the foreland position, there is no direct seismic tie that would constrain a continuation of Palaeozoic cover in the deep subsurface of the Outer Carpathians. In terms of lithology, the $2.49 \mathrm{~g} \cdot \mathrm{cm}^{-3}$ best-fit density concluded for the autochthonous pre-Miocene, may correspond to strongly compacted clastics or a mixture of clastic (less dense) and carbonate (denser) lithologies. In terms of age, these can be Palaeozoic or Mesozoic strata or both.
Less pre-Miocene erosion in the foreland than below the Outer Carpathians is evident, regardless of the age of the pre-Miocene stratigraphy. If the pre-Miocene autochthon is only Palaeozoic, the total erosion is a cumulative effect of the entire post-Variscan geological evolution of the southern margin of the NEP and particular uplift/erosion components known from the regional geology (late Carboniferous, late Cretaceous-Paleocene, Oligoceneearly Miocene) cannot be isolated. If the pre-Miocene autochthon is Mesozoic, it implies not only less erosion in the south but most likely also more subsidence, as the thickness above $2 \mathrm{~km}$ is higher than the composite Mesozoic (Jurassic-Cretaceous) sections in the Carpathian foreland (McCann et al. 2006; Oszczypko et al. 2006). If so, the increased Mesozoic thickness below the Outer Carpathian fold-and-thrust belt may be the first sign of a syn-rift subsidence related to the Outer Carpathian opening sedimentary basins farther south (Golonka et al. 2006). We consider the latter scenario less likely because the crystalline basement's modelled top remains roughly parallel to the Moho, hence no extension-related thinning is observed. An approximately constant thickness of the foreland plate is consistent with the velocity structure of the CEL01 and CEL04 refraction lines crossing the Outer Carpathians (Środa et al. 2006).

The southward slope of crystalline basement attains on average an angle of $5^{\circ}$ along with the down-dip distance of $70 \mathrm{~km}$. It is probably the slope of basal detachment from the time when the Carpathian fold-and-thrust belt was emplaced. A dip angle of this potential detachment 
Fig. 16 Depth to crystalline basement together with the interpreted basementrooted structural elements and isobath contour lines.

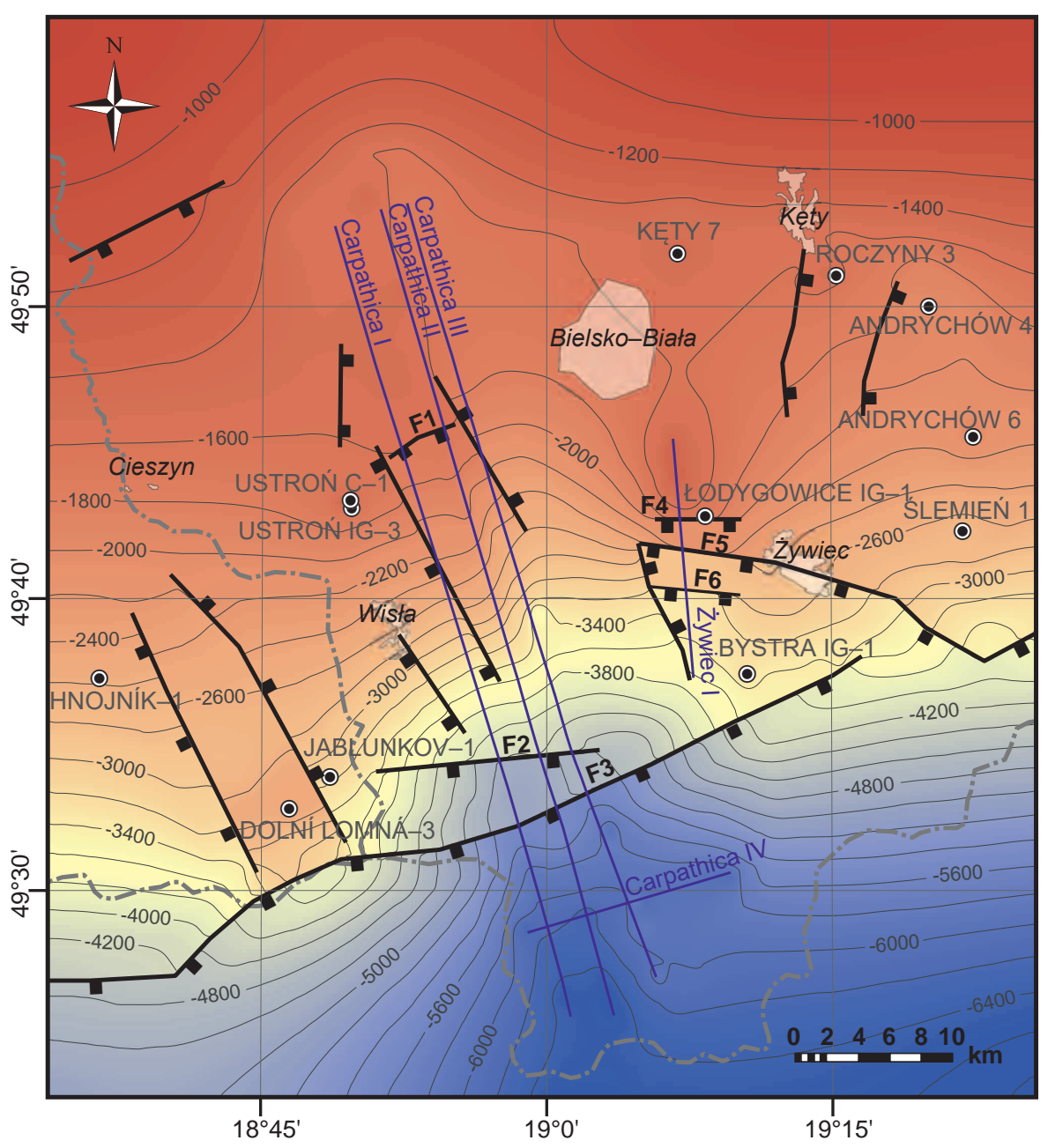

magnetic maps (Fig. 2). This interpretation is consistent with the results of Jablunkov-1 borehole (see Tab. 1 and Fig. 3), which encountered diorites directly below the Devonian and Carboniferous cover of the NEP. The presence of intermediate and mafic rocks, i.e., diorites and gabbros, is also supported by the geological map of the crystalline basement (Dudek 1980; Picha et al. 2006), and potential fields analysis performed by Gnojek and Hubatka (2001), who delineated a positive magnetic anomaly associated with the presence of the Jablunkov Massif adjacent to the $\mathrm{SMH}$ from the west. The elongated body of intermediate to mafic rocks in the basement of the Brunovistulian Terrane may represent a relic of Cadomian arc comparable to that existing in the Brno Massif of southern Moravia. The latter is represented by an Andean-type magmatic arc existing on the Pannotia/Gondwana active margin ca. $600 \mathrm{Ma}$ (Hanžl et al. 2019). A direct link of the SMH and SMB anomalies to metabasite and diorite zones of the Brno Massif is also not excluded, but further studies are needed to explore this concept.

The top of basement grids published by Majdański (2012) and Grad and Polkowski (2016), based on the 
seismic data from refraction soundings, show low resolution at the scale of the study area. Consequently, they cannot replicate even a general trend of basement structure. In a qualitative sense, the closest to our results is the map published by Alasonati Tašárová et al. (2016; their Fig. 7a), although the resemblance is only at a broad scale due to a low resolution of the latter. Therefore, the basement depth postulated by Alasonati Tašárová et al. (2016) is still about 1000 meters deeper than that in the present study.

\section{Conclusions}

The depth to basement derived from the potential field modelling is deeper by c. $2000 \mathrm{~m}$ in the southern part of the study area than that presented in previous basement maps (Paul et al. 1996; Buła and Habryn 2008). Consequently, the southward slope of the crystalline basement beneath the western Outer Carpathians attains on average an angle of $5^{\circ}$ corresponding to the slope of a basal detachment of the Carpathian foldand-thrust belt. Moreover, an approximately $2 \mathrm{~km}$ thick wedge of autochthonous sediments, gradually thinning out toward the north, exists between the basement and the fold-and-thrust belt's sole detachment. The autochthonous sediments may correspond either to Palaeozoic or Mesozoic rocks, or both. Since the modelled top of the crystalline basement is roughly parallel to the Moho no extension-related thinning is recorded, the situation that favour pre-Permian age of autochthonous sediments.

A positive magnetic anomaly, the $\mathrm{SMH}$, in the south of the study area is associated with the increased magnetic susceptibility of the basement rather than a depth to magnetic sources. The anomaly indicates the presence of an elongated body of intermediate to mafic rocks in the basement of the Brunovistulian Terrane. These rocks may represent a relic of Cadomian magmatic arc that is comparable to that existing in the Brno Massif of southern Moravia.

Acknowledgements. M. Mikołajczak and S. Mazur acknowledge financial support from the Polish National Science Centre Grant no. UMO-2017/25/B/ST10/01348. J. Barmuta and K. Starzec acknowledge support from Statutory Works, Blue Gas II - ShaleCarp, 'departments' colleagues and consent to use Move Suite by Petex Ltd. Łukasz Gągała is thanked for critical comments during the preparation of the manuscript. The authors thank Alexandra Guy and Jakub Plášil for editorial handling of the paper. Constructive comments from Yuriy Maystrenko and Anonymous Reviewer significantly contributed to improving our work.

\section{References}

Alasonati TašÁrova Z, Fullea J, Bielik M, Środa P (2016) Lithospheric structure of Central Europe: Puzzle pieces from Pannonian Basin to Trans-European Suture Zone resolved by geophysical-petrological modeling. Tectonics 35: 722-753

Barmuta J, Mikolajczak M, Starzec K (2019) Constraining depth and architecture of the crystalline basement based on potential field analysis - the westernmost Polish Outer Carpathians. J Geosci (Czech Republic) 64: 161-177

BARnes G, BARRAud J (2012) Imaging geologic surfaces by inverting gravity gradient data with depth horizons. Geophysics 77: G1-G11

Blakely RJ (1995) Potential Theory in Gravity and Magnetic Applications. Cambridge university press. DOI: 10.1017/CBO9780511549816

Bojdys G, Grabowska T, Medoń Z (2008) Two dimensional gravity modelling in Polish Western Carpathians (in Polish with English abstract). Geologia 34:147-170

BuŁa Z, Habryn R (2008) Geological-structural atlas of the Palaeozoic basement of the Outer Carpathians and Carpathian foredeep. Państwowy Instytut Geologiczny, Warsaw, pp 1-74 (in Polish)

BuŁa Z, Habryn R (2011) Precambrian and Palaeozoic basement of the Carpathian foredeep and the adjacent outer Carpathians (SE Poland and Western Ukraine). Ann Soc Geol Pol 81: 221-239

BuŁA Z, ŻABA J (2008) Structure of the Precambrian basement of the eastern part of the Upper Silesian block (Brunovistulicum). Prz Geol 56(6): 473-480 (in Polish with English summary)

Central Geological Database (2020) In: Polish Geol. Inst. http://baza.pgi.gov.pl/. Accessed 6 Jul 2020 (WWW document)

Decelles PG, Robinson DM, Quade J, Ojha TP, Garzione CN, Copeland P, UpReti BN (2001) Stratigraphy, structure, and tectonic evolution of the Himalayan fold-thrust belt in western Nepal. Tectonics 20: 487-509

DĚDÁČEK K, GNOJEK I, ChLupáČová M (1997) Regionalsize magnetic anomalies and their sources in the deep structure of Moravia and Silesia. Geol vyzk Mor Slez v r 1996, Brno 1-55, (in Czech)

DudEK A (1980) The crystalline basement block of the Outer Carpathians in Moravia: Bruno-Vistulicum. Rozpr Cs Akad Věd, ̌̌ mat-prir Věd, Praha, 1-85

ELKINS TA (1951) The second derivative method of gravity interpretation. Geophys 16(1): 29-50

Gągala Ł, Vergés J, Saura E, Malata T, Ringenbach JC, Werner P, Krzywiec P (2012) Architecture and orogenic evolution of the northeastern Outer Carpathians from cross-section balancing and forward modeling. Tectonophysics 532-535: 223-241 
Gawęda A, Golonka J, WaśKowska A, Szopa K, Chew D, Starzec K, WieczoreK A (2019) Neoproterozoic crystalline exotic clasts in the Polish Outer Carpathian flysch: remnants of the Proto-Carpathian continent? Int J Earth Sci 108:1409-1427

GNOJEK I, HubaTKa F (2001) Structure of the Brunovistulian unit (E part of the Czech Republic) on the basis of seismic and magnetic data. Vestn Ces Geol Ust 76: 157-168

Golonka J, Oszczypko N, Ślączka A (2000) Late Carboniferous-Neogene geodynamic evolution and paleogeography of the circum-Carpathian region and adjacent areas. Ann Soc Geol Pol 70: 107-136

Golonka J, Gahagan L, Krobicki M, Marko F, OszcZYPKO N, ŚlĄCZKA A (2006) The Carpathians and Their Foreland: Geology and Hydrocarbon Resources: AAPG Memoir 84. In: GolonkA J, PICHA F (ed) The Carpathians and Their Foreland: Geology and Hydrocarbon Resources. AAPG Memoir 84, pp 11-46

Grabowska T, Bojdys G (2001) The border of the EastEuropean Craton in South-Eastern Poland based on gravity and magnetic data. Terra Nov 13: 92-98

Grabowska T, Bojdys G, Dolnicki J (1998) Threedimensional density model of the Earth's crust and the upper mantle for the area of Poland. J Geodyn 25: 5-34

Grabowska T, Bojdys G, Lemberger M, Medoń Z (2007) Geophysical-and-geological interpretation of gravity and magnetic anomalies in Polish Western Carpathians (in Polish with English abstract). Geologia 33: 103-126

Grabowska T, Bojdys G, BieliK M, Csicsay K (2011) Density and magnetic models of the lithosphere along CELEBRATION 2000 profile CEL01. Acta Geophys 59: 526-560

Grad M, Polkowski M (2016) Seismic basement in Poland. Int J Earth Sci 105: 1199-1214

Grad M, Guterch A, Mazur S (2002) Seismic refraction evidence for crustal structure in the central part of the Trans-European Suture Zone in Poland. In: WincheSTER JA, Pharaoh TC VJ (ed) Geological Society Special Publication. Geological Society of London, pp 295-309

Guterch A, Grad M (2006) Lithospheric structure of the TESZ in Poland based on modern seismic experiments. Geol Q 50: 23-32

Hanžl P, Janoušek V, Soejono I, Buriánek D, Svojtka M, HrdličKová K, ERBAN V, PIN C (2019) The rise of the Brunovistulicum: age, geological, petrological and geochemical character of the Neoproterozoic magmatic rocks of the Central Basic Belt of the Brno Massif. Int J Earth Sci 108: 1165-1199

KrzYwIEC P (2001) Contrasting tectonic and sedimentary history of the central and eastern parts of the Polish Carpathian foredeep basin - results of seismic data interpretation. Mar Pet Geol 18(1), 13-38

Krzywiec P, Oszczypko N, Bukowski K, OszczypkoClowes M, Śmigielski M, Stuart FM, Persano C,
SINCLAIR HD (2014) Structure and evolution of the Carpathian thrust front between Tarnów and Pilzno (Pogórska Wola area, southern Poland) - results of integrated analysis of seismic and well data. Geol Q 58(3): 409-426

KSIĄŻKIEWICZ M (1960) Zarys paleogeografii polskich Karpat fliszowych (in Polish). Pr Inst Geol 30: 209-231

Linnemann U, 'D'Lemos R, Drost K, JefFries, T, Gerdes A, Romer R, Samson S, Strachan R (2008) The Geology of Central Europe, Volume 1: Precambrian \& Palaeozoic. In: MCCANN T (ed). Geological Society of London, London, pp 103-154

MAJDAŃSKI M (2012) The structure of the crust in TESZ area by kriging interpolation. Acta Geophys 60: 59-75

Maystrenko Y, Scheck-Wenderoth M (2009) Density contrasts in the upper mantle and lower crust across the continent-ocean transition: Constraints from 3-D gravity modelling at the Norwegian margin. Geophys J Int 179: 536-548

Maystrenko Y, Scheck-Wenderoth M (2013) 3D lithosphere-scale density model of the Central European Basin System and adjacent areas. Tectonophysics 601: 53-77

Mazur S, Mikolajczak M, Krzywiec P, Malinowski M, Lewandowski M, Buffenmyer V (2016) Pomeranian Caledonides, NW Poland - A collisional suture or thinskinned fold-and-thrust belt? Tectonophysics 692: 29-43

Mccann T, Pascal, C, Timmerman MJ, Krzywiec P, Lopez-Gomez J, Wetzel L, KrawczyK CM, Rieke H, LAMARChe J (2006) Post-Variscan (end CarboniferousEarly Permian) basin evolution in Western and Central Europe. In: GeE DG, Stephenson RA (eds) European Lithosphere Dynamics. Geological Society, London, Memoirs, 32, pp. 355-388

Meyer B, Saltus R, Chulliat A (2016) EMAG2: Earth Magnetic Anomaly Grid (2-arc-minute resolution) Version 3. National Centers for Environmental Information, NOAA. Model. Natl. Centers Environ. Information, NOAA 5194

Moritz, H (2000) Geodetic Reference System 1980. J Geodesy 74: 128-133

Moryc W (2005) Development of research on Western Carpathian Miocene deposits in the Bielsko-Kraków area (in Polish with English summary). Geologia 43(1): 5-73

OszCZYPKo N (2006) Late Jurassic-Miocene evolution of the Outer Carpathian fold-and-thrust belt and its foredeep basin (Western Carpathians, Poland). Geol Q 50: 169-194

Oszczypko N, Malata E, Švábenická L, Golonka J, MARKo F (2004) Jurassic-Cretaceous controversies in the Western Carpathian Flysch: The "black flysch" case study. Cretac Res 25: 89-113

Oszczypko N, Krzywiec P, Popadyuk I, Peryt T (2006) Carpathian Foredeep Basin (Poland and Ukraine): Its sedimentary, structural, and geodynamic evolution. In: Golonka J, Picha FJ (eds) The Carpathians and their 
foreland: geology and hydrocarbon resources. AAPG Memoir 84, pp. 261-318

Paul Z, RyŁko W, Tomaś A (1996) Influence of tectonic of the consolidated basement of the Carpathians on distribution of flysch masses in the Polish part of the western Carpathians. Kwart Geol 40: 487-500 (in Polish with English abstract)

PFIFFner OA (2017) Thick-skinned and thin-skinned tectonics: a global perspective. Geosciences 7(3), 71

Picha FJ, Stráník Z, Krejčí O (2006) Geology and hydrocarbon resources of the Outer Western Carpathians and their foreland, Czech Republic. In: Golonka J, PicHA FJ (eds) The Carpathians and their foreland: Geology and hydrocarbon resources: AAPG Memoir, 84: 49-175

Rime V, Sommaruga A, Schori M, Mosar J (2019) Tectonics of the Neuchâtel Jura Mountains: insights from mapping and forward modelling. Swiss J Geosci 112: 563-578

Sandwell DT, Müller RD, Smith WHF, Garcia E, FRANCIS R (2014) New global marine gravity model from CryoSat-2 and Jason-1 reveals buried tectonic structure. Science 346: 65-67

Smith G, Mcneill L, Henstock TJ, Bull J (2012) The structure and fault activity of the Makran accretionary prism. J Geophys Res: Solid Earth, 117(B7)

Starzec K, Barmuta J, Stefaniuk M (2017) The structure of the Silesian and Magura units in the westernmost Polish Outer Carpathians. In: International Multidisciplinary Scientific GeoConference Surveying Geology and Mining Ecology Management, SGEM, pp 477-484
Ślączka A, Krugłov S, Golonka J, Oszczypko N, PoPADYUK I (2006) Geology and Hydrocarbon Resources of the Outer Carpathians, Poland, Slovakia, and Ukraine: General Geology. In: The Carpathians and Their Foreland: Geology and Hydrocarbon Resources: AAPG Memoir 84, pp 221-258

Środa P, Czuba W, Grad M, Guterch A, Tokarski AK, Janik T, Rauch M, Keller GR, Hegedüs E, VozÁr J, Celebration 2000 Working Group (2006) Crustal and upper mantle structure of the Western Carpathians from CELEBRATION 2000 profiles CEL01 and CEL04: seismic models and geological implications. Geophys J Int 167: 737-760

Talwani M, Ewing M (1960) Rapid Computation of Gravitational Attraction of Three-Dimensional Bodies of Arbitrary Shape. Geophysics 25: 203-225

Wang JM, Zhang JJ, Liu K, Zhang B, Wang X, Rai SM, Scheltens M (2016) Spatial and temporal evolution of tectonometamorphic discontinuities in the central Himalaya: Constraints from $\mathrm{P}-\mathrm{T}$ paths and geochronology. Tectonophysics 679: 41-60

ŻElaźniewicz A, BuŁa Z, FAnning M, Seghedi A, Żaba $\mathrm{J}$ (2009) More evidence on Neoproterozoic terranes in Southern Poland and southeastern Romania. Geol Q 53: $93-124$

Żelaźniewicz A, Oberc-Dziedzic T, Slama J (2020) Baltica and the Cadomian orogen in the Ediacaran-Cambrian: a perspective from SE Poland. Int J Earth Sci 109: 1503-1528 